A Research Report for the Rockwell Hanford Operations

\title{
Analysis of Small Mammal Populations Inhabiting the Environs of a Low-Level Radioactive Waste Pond
}

K. A. Gano

March 1979

Prepared for the U.S. Department of Energy under Contract No. EY-76-C-06-1830

Pacific Northwest Laboratory Operated for the U.S. Department of Energy by 
NOTICE

This report was prepared as an account of work sponsored by the United States Government. Neither the United States nor the Department of Energy, nor any of their employees, nor any of their contractors, subcontractors, or their employees, makes any warranty, express or implied, or assumes any legal liability or responsibility for the accuracy, completeness or usefulness of any information, apparatus, product or process disclosed, or represents that its use would not infringe privately owned rights.

The views, opinions and conclusions contained in this report are those of the contractor and do not necessarily represent those of the United States Government or the United States Department of Energy.

\author{
PACIFIC NORTHWEST LABORATORY \\ operated by \\ BATTELLE \\ for the \\ UNITED STATES DEPARTMENT OF ENERGY \\ Under Contract EY-76-C-06-1830
}

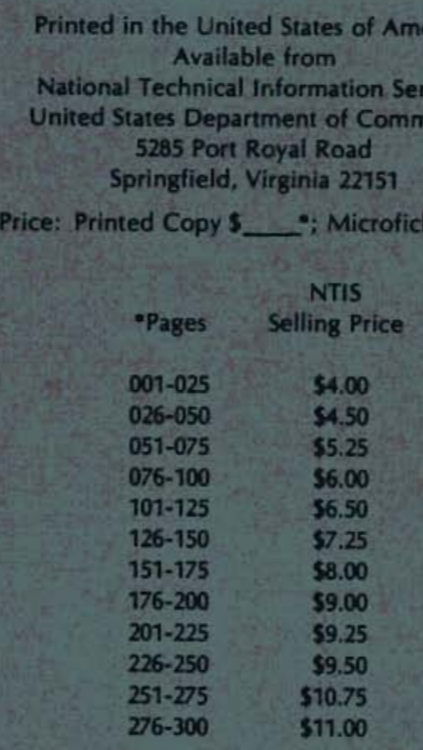




\section{Analysis of Small Mammal Populations Inhabiting the Environs of a Low-Level Radioactive Waste Pond*}

K. A. Gano

March 1979

Prepared for

the U.S. Department of Energy

under Contract No. EY-76-C-06-1830

*This research was performed as part of

Rockwell Hanford Operations' Site Characterization Activity, Long-Term Management of Low-Level Waste Program, coordinated by Keith Price.

Pacific Northwest Laboratory

Richland, Washington 99352 


\section{ACKNOWLEDGMENTS}

This study was supported by the Rockwell Hanford Operations Long-Term Management of Low-Level Waste Program under Contracts EY-77-C-06-2130 and EY-76-C-06-1830.

In developing our concepts, we have drawn extensively on the data base, design paradigms and professional experience of staff associated with research programs funded by the Office of Health and Environmental Research of the Department of Energy. Thanks are extended to the people who participated in and contributed to this study. Rockwell scientist D. Paine and Battelle scientists W. H. Rickard, L. E. Rogers, R. G. Schreckhise, G. W. Endres and L. L. Cadwell gave helpful suggestions and advice on data interpretation. C. A. Lee, M. A. Rumble and W. D. Steigers assisted in small mammal trapping and data collection. Dosimeter analysis was performed by F. N. Eichner. 


\section{SUMMARY}

This study was designed to determine the kinds of small mammals living adjacent to 216-U-10 Pond, the radiation exposures these mice received, and the level and type of radionuclides assimilated while living next to this pond and the 216-Z-19 Ditch. This information will ultimately be used to estimate biologic transport of radionuclides in the pond area.

Four species of mice were trapped and included the Great Basin pocket mouse (Perognathus parvus), deer mouse (Peromyscus maniculatus), house mouse (Mus musculus), and the western harvest mouse (Reithrodontomys megalotis).

Animals were collected throughout the study and composite tissue samples were analyzed by gamma spectrometry. Also, an analys is for $238 \mathrm{Pu}, 239,240 \mathrm{Pu}$ and ${ }^{241} \mathrm{Am}$ was performed. The most abundant gamma emitter was ${ }^{137} \mathrm{Cs}$ with the highest levels occurring at three trapping locations: one near the 216-Z-19 Ditch and two locations adjacent to the pond. House mice captured near the 216-Z-19 Ditch showed the highest levels with one gastrointestinal (GI) tract sample having $1600 \mathrm{pCi}{ }^{137} \mathrm{Cs} / \mathrm{g}$ dry weight.

Four tissue types from resident mice were analyzed for $\mathrm{Pu}$ and Am concentrations. The tissues analyzed were fur-skin, liver, lung, and muscle-bone. The highest concentration detected was $2.03 \mathrm{pC}$ i $239,240 \mathrm{Pu} / \mathrm{g} \mathrm{dry}$ weight in a fur-skin sample from house mice captured on the meadow transect near the pond.

Results from radiochemical analyses of mouse tissues showed that pocket mice have the lowest concentrations of radionuclides. They were also less frequently trapped on the two riparian transects near the pond. This may be attributed to food and habitat preference. Pocket mice generally prefer the Artemisia tridentata-Bromus tectorum vegetation type to riparian habitats such as the pond and ditches.

Another part of this study involved dosimeters implanted in resident mice to determine gamma exposure. Analyses revealed that mice living in the meadow transect adjacent to the pond receive the highest exposure. Again, house mice had the highest, with an average $54.9 \mathrm{R} / \mathrm{yr}$.

Dosimeters were placed in the soil along the trapping transects to measure gamma and thermal neutron exposure rates at each dm of soil to a depth of $5 \mathrm{dm}$. This showed the stratification of exposure rates in a $5-\mathrm{dm}$ soil profile. The top decimeter of soil had the highest exposure rate with a mean of $75 \mathrm{R} / \mathrm{yr}$ in the meadow. Neutron dose in the soil was also highest near the surface with $37 \mathrm{mrad} / \mathrm{yr}$ average in the meadow. 


\section{CONTENTS}

ACKNOWLEDGMENTS

SUMMARY

LIST OF FIGURES

LIST OF TABLES

INTRODUCTION

SITE DESCRIPTION

METHODS

RESEARCH AND ANALYSIS

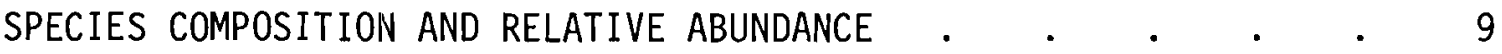

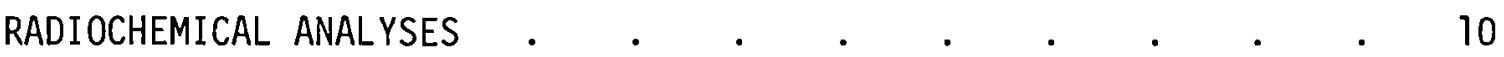

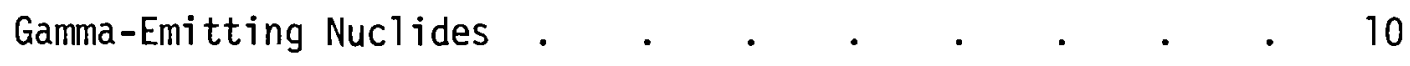

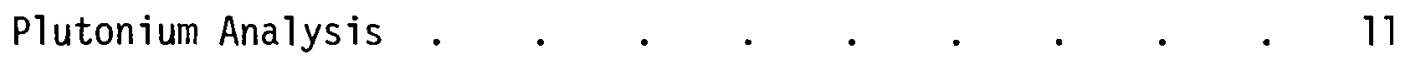

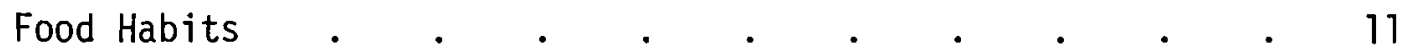

GAMMA EXPOSURES TO SMALL MAMMALS $. \quad . \quad . \quad . \quad . \quad . \quad . \quad 14$

EDAPHIC EXPOSURE RATES . $. \quad . \quad . \quad . \quad . \quad . \quad . \quad . \quad 15$

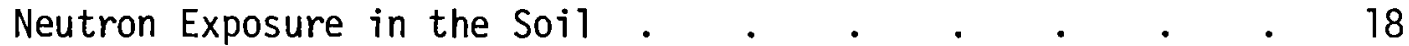

CONCLUSIONS

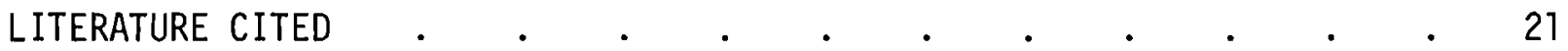

APPENDIX A

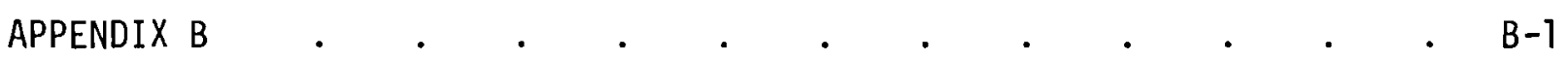

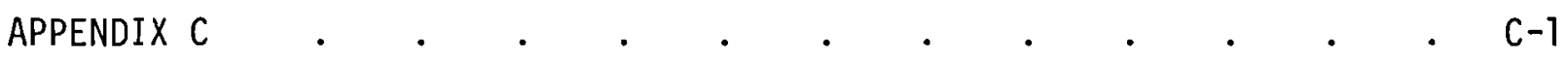

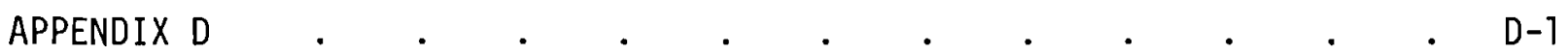

APPENDIX E $\quad . \quad . \quad . \quad . \quad . \quad . \quad . \quad . \quad . \quad . \quad . \quad E-1$ 


\section{LIST OF FIGURES}

1 Map of Hanford Area Showing U-Pond . $\quad . \quad$. $\quad . \quad$. $\quad . \quad$ e 2

2 U-Pond Smal1 Mammal Transects . . . . . . . . 3

3 Anesthetized Pocket Mouse Being Implanted with Dosimeter Packet . . . . . . . . . . . 6

4 Dowel Showing Surface Location of Dosimeters

5 a Concentrations of Plutonium and Americium

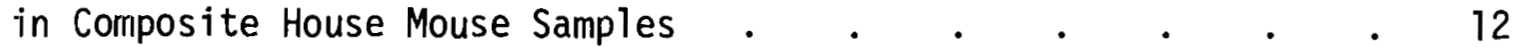

5b Concentrations of Plutonium and Americium

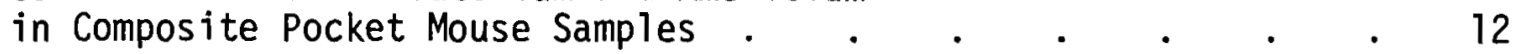

5c Concentrations of Plutonium and Americium

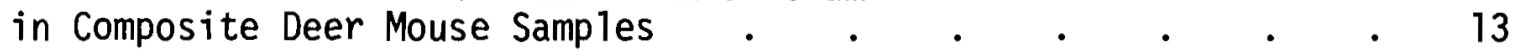

$5 d$ Concentrations of Plutonium and Americium in Composite Harvest Mouse Samples . . . . . . . . 13

6 Gamma Exposure to Mice Living Along

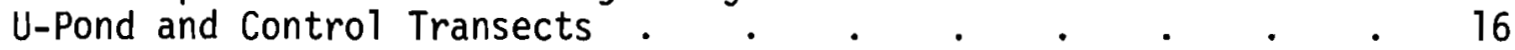

7 Gamma Exposure to Soil Along U-Pond Transects . . . . 17

8 Cross Section of Z-19 Ditch Showing 


\section{LIST OF TABLES}

1 Total Number of Animals Captured and Percentage of Each Species on U-Pond and Control Transects . . . . . . . . . 9

2 U-Pond Plutonium Analysis on Whole Mice . . . . . . 14

3 Mean Gamma Exposures to U-Pond Mice in R/yr . . . . . 16

4 Mean Gamma Exposure to Soil on U-Pond Transects in R/yr . 17

5 Mean Neutron Exposure to Soil on U-Pond in mrad/yr . . . 18

A. 1 Composite Sample Using Like Tissues from Two or More Animals of Same Species, $\mathrm{pCi}{ }^{137} \mathrm{Cs} / \mathrm{g}$ Dry

A.1.1 Fur-Skin Samples . . . . . . . . . A-1

A.1.2 Liver Samples . . . . . . . . . . . A-2

A.1.3 Kidney Samples . . . . . . . . . . A-3

A.1.4 Lung Samples. . . . . . . . . . A-4

A.1.5 GI Tract Samples . . . . . . . . . . . A-5

A.1.6 Muscle-Bone Samples . . . . . . . . . . A-6

A. 2 Composite Samples Other than ${ }^{137} \mathrm{Cs}, \mathrm{pCi} / \mathrm{g}$ Dry

A.2.1 Sampling Period 9-10 April '75 . . . . . . A-7

A.2.2 Sampling Period 6-7 May '75 . . . . . . . A-8

A.2.3 Sampling Period 23-24 October 75 . . . . . A-9

A.3 U-Pond Samples Collected During 1976-77 and Analyzed as
Individual Animals, pCi/g ${ }^{137} \mathrm{Cs} / \mathrm{g}$ Dry . . . . A-10

A.4 U-Pond Samples Collected During 1976-77 and Analyzed as
Individual Animals, pci/g Dry (Samples Other than ${ }^{137} \mathrm{CS}$ ) . . A-12

B. 1 Isotopic Plutonium and Americium Analysis of U-Pond Mice Using Composite Samples

B.1.1 Concentrations of $238 \mathrm{Pu} / \mathrm{g}$ Dry . . . . . . B-1

B.1.2 Concentrations of ${ }^{239} \mathrm{pu} / \mathrm{g}$ Dry . . . . . . B-2

B.1.3 Concentrations of ${ }^{24} \mathrm{Am} / \mathrm{g}$ Dry . . . . . . B-3

C.1 Mean Gamma Exposure to Small Mammals at . . . . . . . . C-1
U-Pond in mR/wk

C.2 Gamma Exposure to U-Pond Mammals in mR/wk . . . . . C-2

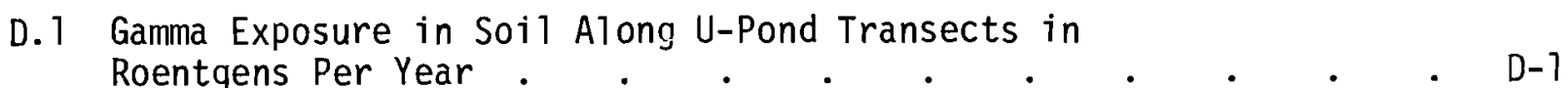


D.2 Neutron Exposure in Soil Along U-Pond Transects in mrads Per Year . . . . . . . . . . . D-3

D.3 Mean Gamma Exposure to Soil on U-Pond Transects in Roentgens Per Year . D-4

E. 1 Total Number of Individual Animals Captured Each Month . . . . . . . . . . . E-1

E.2 Average Number of Animals Captured on U-Pond
Transects Per Trap Session . . . . . . . . E-3 


\section{INTRODUCTION}

Information concerning species composition, concentration of radionuclides taken up by the various species, and external doses of gamma radiation is essential in determining the environmental impact of waste management areas on small mammal populations. Small mammals are potential vectors in the transport of radionuclides away from waste management areas because they provide a food base for many larger, more mobile secondary consumers such as snakes, raptors, badgers, racoons, skunks, and coyotes. For this reason it is important to determine the types and the quantities of nuclides being concentrated by mice living on waste management areas. Also of concern is the exposure rate to the biota on these areas (Energy Research and Development Administration, 1975).

This study was designed to gather information on small mammals living adjacent to 216-U-10 Pond. Radiation exposures to the mice were investigated along with the level and type of radionuclides being assimilated. This information will ultimately be used to estimate biologic transport of radionuclides in the pond area.

To accomplish this objective the following approach was used:

1. Species composition was investigated for mice living near 216-U-10 (U-Pond), a liquid waste disposal site.

2. Tissue samples taken from mice living in the vicinity of 216-U-10 were analyzed for radionuclide content to determine concentrations.

3. Dosimeters were implanted in mice living in the vicinity of the trapping transects on the study areas to provide a means for determining external gamma exposures.

4. To establish exposure distribution in a $5-\mathrm{dm}$ soil profile, dosimeters were buried at $1 \mathrm{dm}$ increments along the transect lines.

This report describes results of these analyses. Appendix A contains results from tissue analysis for gamma emitters, and Appendix B provides summaries of tissue analys is for plutonium and americium-241. Appendix $C$ includes exposure rates of gamma radiation to mice living near the various transects. Appendix D provides information on the stratification of gamma and thermal neutron radiation doses in a $5-\mathrm{dm}$ soil profile along each transect and Appendix $E$ contains information on trapping results.

\section{SITE DESCRIPTION}

The study areas are located on the Department of Energy's Hanford Site in Benton County, southcentral Washington (Figure 1). These areas consist of the U-Pond study site, specifically 216-U-10 (Figure 2), located within the confines of the 200 West perimeter fence, a control plot near U-Pond, and an additional control site on the Arid Lands Ecology (ALE) Reserve at Rattlesnake Springs, established to correspond with the riparian vegetation at U-Pond. 


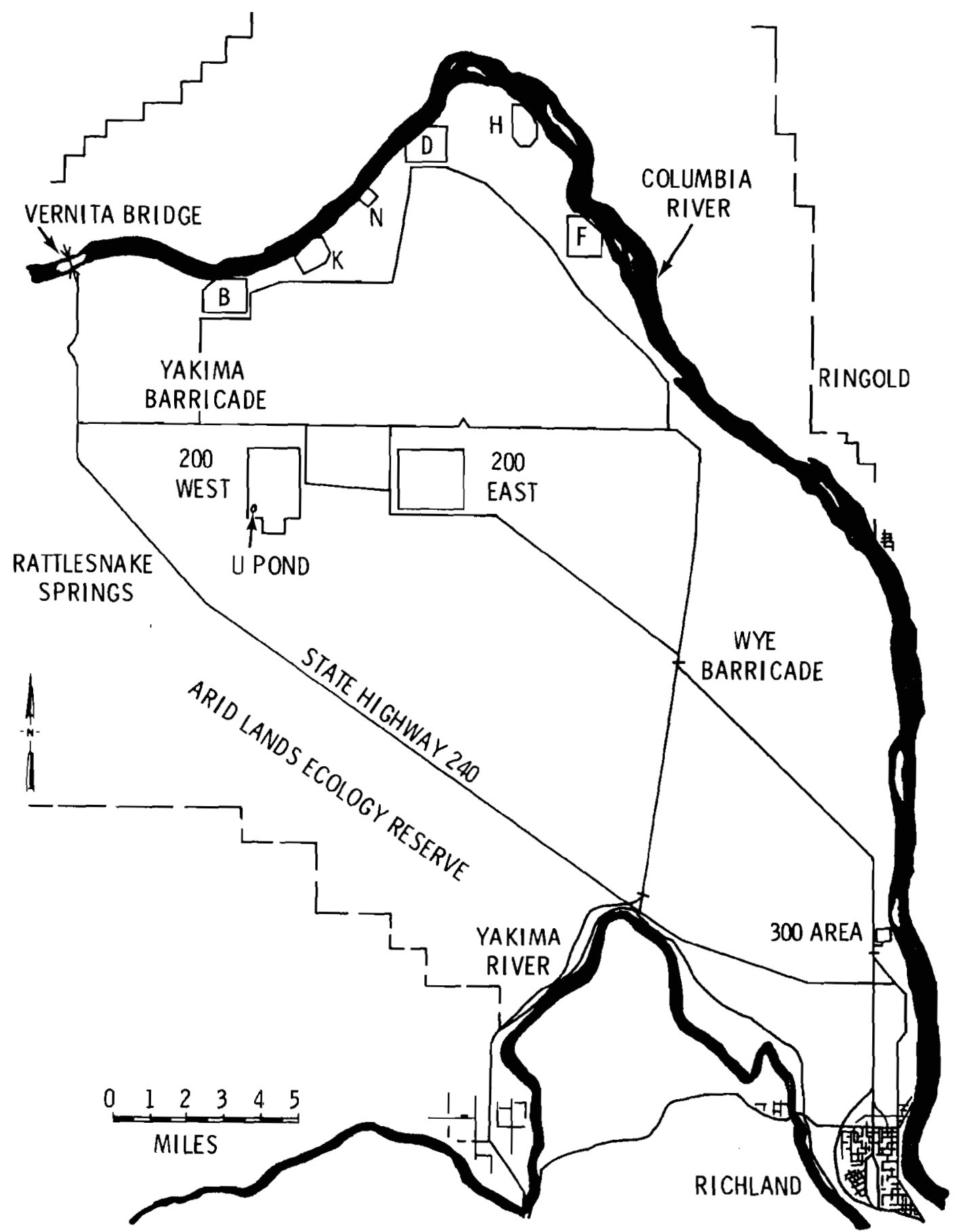

FIGURE 1. Map of Hanford Area Showing U-Pond 
U-Pond was established in 1944 in a shallow depression in the 200 west Area of the Hanford Site. Its function was to receive low-level radioactive wastes, primarily cooling water, and laundry waste water. The pond presently receives water from three major sources: a plutonium processing plant via 216-Z-19 Ditch, a laundry where protective clothing is washed (via 216-U-14 Ditch), and an evaporator crystallizer plant which reduces liquid rad-wastes to salt cakes via $216-U-14$ Ditch.

U-Pond is the oldest liquid waste disposal site on the Hanford Site. Since its origin, a diverse riparian vegetation has developed, creating an attractive habitat for many animals otherwise not common to this arid environment (Fitzner and Rickard, 1975).

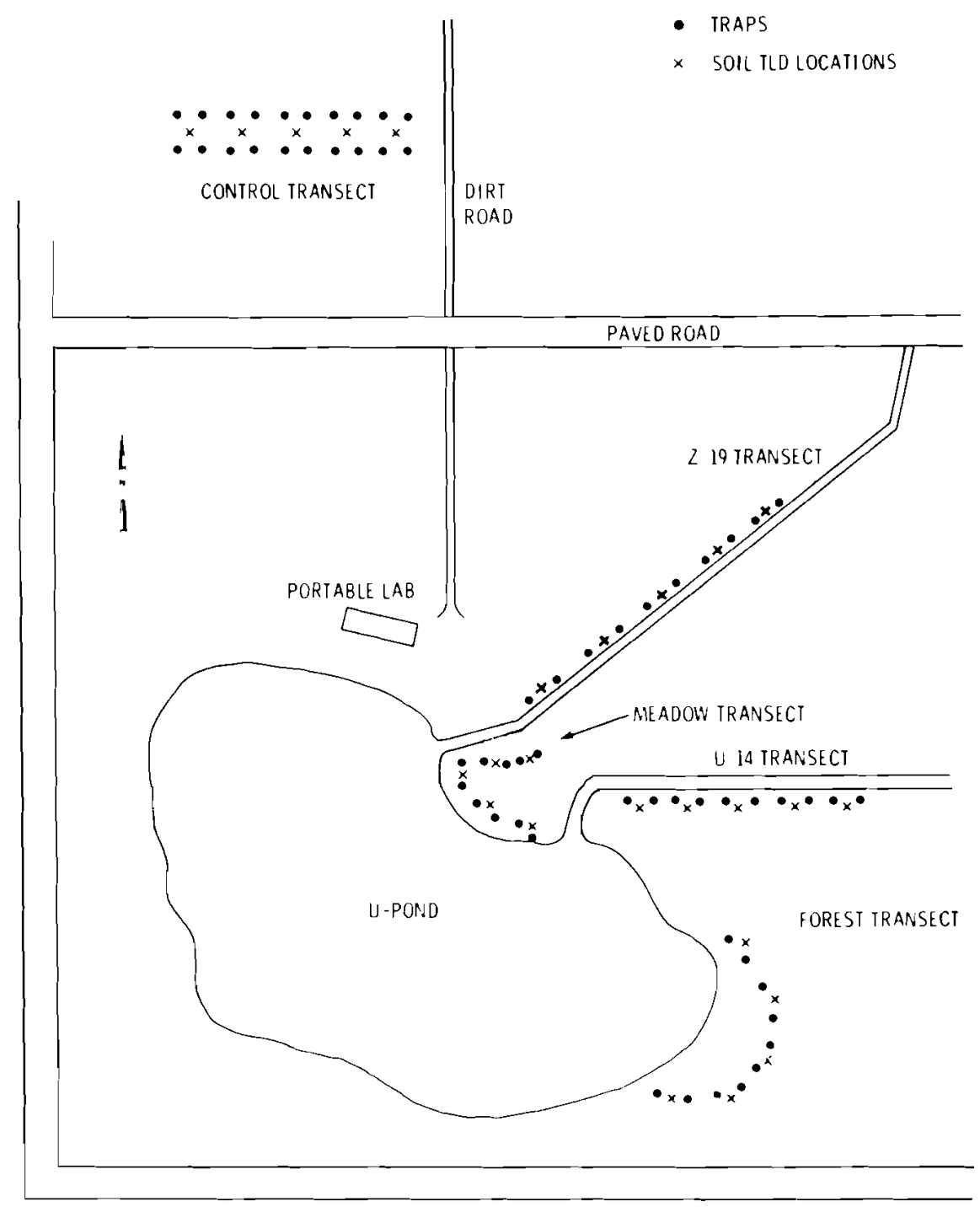

FIGURE 2. Uं-Pond Smal1 Mammal Transects 


\section{METHODS}

Trap lines were established at the U-Pond study site using Sherman live traps. Four transects were set up near the pond. These transects each contained 10 traps. There were two different habitat types represented. A trap line along the Z-19 Ditch and one along the U-14 Ditch represented a desert habitat of sagebrush-cheatgrass with access to free water. The riparian habitat adjacent to the pond was represented by two transects, one in the smal1 delta region between the two ditches (Meadow transect), and one near the south end of the pond in a wooded area, the Forest transect (Figure 2).

Two control transects were located in noncontaminated areas away from the pond. One control transect was located inside the 200 West perimeter fence in a sagebrush-cheatgrass area approximate 1 y $1 / 4$ mile from U-Pond. It contained two lines of 10 traps each for a total of 20 traps. The second control transect on the Arid Lands Ecology Reserve at Rattlesnake Springs contained 40 traps. Sixteen trapping sessions were conducted at the U-Pond study site and control transects. Trapping commenced in April 1975 and ended in July 1977.

The first phase of the study investigated radionuclide concentrations in the small mammals living near the pond. The trap lines were operated during April, May and October 1975, and the mice submitted for radiochemical analysis. After each trap session the animals were brought into the lab and separated by species and transect. They were then dissected into various tissues with each like sample of same species and location combined to make composite samples. For example, all the livers from pocket mice captured on the $Z$ transect during one trap session were combined to make one sample.

During the first sample session in April 1975, the composite samples consisted of muscle-bone, fur-skin, head, feet-tail, lung, liver, kidney, testes, ovary, and gastrointestinal tract. During the sample periods of May and October 1975, four of the sample types were discontinued. The "head" and the "feet-tail" samples were not used because in both cases there were inseparable internal and external structures, e.g., bone, muscle and fur-skin on the "feettail" sample, making it impossible to determine the location of detectable radionuclides. The testes and ovary samples were also discontinued due to insufficient tissue mass to obtain val id counting results. Therefore, the samples used in the following two sample sessions were fur-skin, liver, lung, kidney, gastrointestinal tract, and muscle-bone (the remaining carcass).

The samples were oven-dried at $50^{\circ} \mathrm{C}$ for $48 \mathrm{hr}$ and then analyzed by gamma spectrometry. Samples from each transect with significant ${ }^{137} \mathrm{Cs}$ concentrations above control values were selected and analyzed for plutonium concentrations. Samples from May and October sessions were analyzed for specific plutonium and americium, i.e., $238 \mathrm{Pu}, 239-240 \mathrm{Pu}$, and ${ }^{241} \mathrm{Am}$ by LFE Environmental Analysis Laboratories, Richmond, California.

Tissue samples were taken throughout the study periogd for radiochemical analys is and included whole body samples for plutonium analysis. Two other 
sample types were used to represent analysis from single animals. An exterior sample containing fur-skin and feet-tail and an interior sample containing the remaining intact carcass were used for gamma scan analys is. These samples of individual animals, when compared with the composite samples, were not significantly different.

Environmental exposure rates of gamma radiation were investigated by using thermoluminescent dosimeters (TLD-700角). Exposures to mice living in the vicinity of the various transects were determined by surgically implanting dosimeter packets under the skin at the back of the neck. The mice were given individual identification numbers using a series of toe amputations. The species, location, age, reproductive condition and weight were recorded for future reference. They were then transported to a portable lab at the U-Pond site where dosimeters could easily be implanted. The animals were anesthetized and a small incision made on the back of their necks. Two dosimeters sealed in a plastic packet approximately $7 \mathrm{~mm} \times 10 \mathrm{~mm}$ were inserted under the skin and sutured (Figure 3 ).

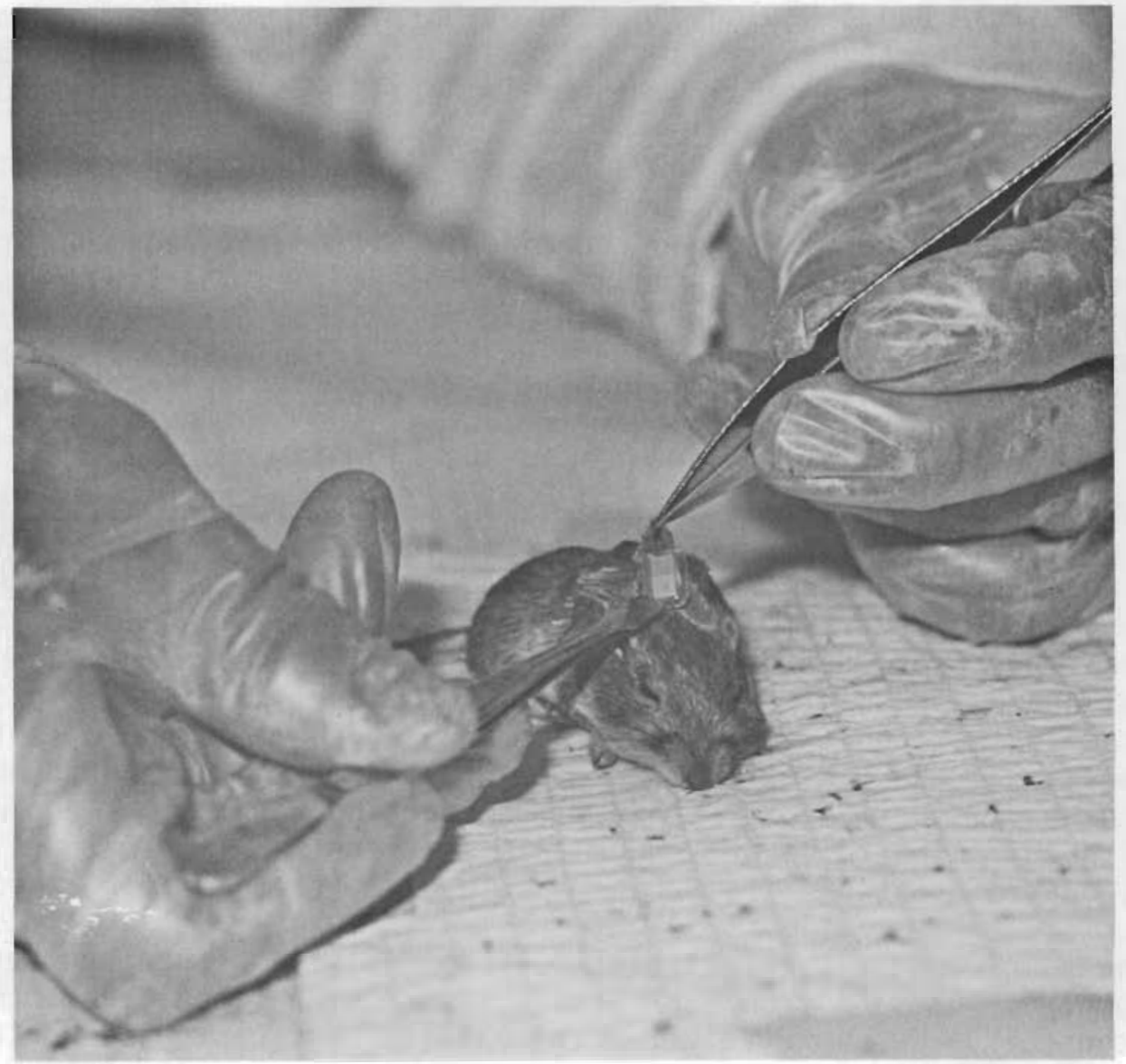

Neg. PNL 75064-230 CN

FIGURE 3. Anesthetized Pocket Mouse Being Implanted With Dosimeter Packet

(B) Harshaw Chemical Company, LiF ${ }_{2}$. Use does not imply Battelle endorsement. 
Following the operation the mice were returned to their respective points of capture and released. Approximately 1 month later the trap lines were operated again and the recovered TLDs exchanged. Concurrently, newly captured mice were implanted with TLDs.

The TLD 700s used in this study were calibrated for exposure dose in air with a ${ }^{226} \mathrm{Ra}$ source. Therefore, al1 exposure data from TLD 700 s are reported in roentgens $(R)$. Totally accurate measurements of absorbed doses in U-Pond mice are extremely difficult to interpolate. Calculations necessary to determine absorbed dose from known exposed dose employ a conversion factor which uses the effective atomic number of the irradiated medium along with the energies of the ionizing radiations. The following expression is used for this conversion when the photon energy and mass absorption coefficient of the exposed medium are known (Arena, 1971).

$$
\text { Rads (absorbed dose) }=\left[0.869 \frac{\mu / \rho \text { of material }}{\mu / \rho \text { of air }}\right] R \text { (exposed dose) }
$$

where the $\mu / \rho$ values are the mass absorption coefficients for the absorbing material and air. The mass absorption coefficients are functions of the energy of the incident photons and the atomic number of the absorbing medium.

If one assumes that the energies of the incident photons at U-Pond were equal to $0.1 \mathrm{MeV}$, and only soft tissues of the mice were considered then the mass absorption coefficients are $0.0252 \mathrm{~cm}^{2} / \mathrm{g}$ for the material and $0.0231 \mathrm{~cm}^{2} / \mathrm{g}$ for air (NBS Handbook 85, 1964). The absorbed dose would then be equal to

$$
\text { rads }=\left[0.869 \frac{0.0252 \mathrm{~cm}^{2} / \mathrm{g}}{0.0231 \mathrm{~cm}^{2} / \mathrm{g}}\right] \mathrm{R}=(0.95) \mathrm{R}
$$

Dosimeters were also placed in the soil along the transect lines. There were five locations on each transect. At each location, aluminum tubing, $5.5 \mathrm{dm}$ long by $1.9 \mathrm{~cm}$ in diameter and a wall thickness of approximately $1 \mathrm{~mm}$, was driven into the soil. Dosimeters were attached to a wooden dowel at 1-dm intervals and the dowel placed inside the aluminum tubing (Figure 4). The dosimeter locations started at the soil surface and went to a depth of $5 \mathrm{dm}$.' Along with TLD 700s, which are primarily for detecting gamma radiation, TLD 600 s were also used at each depth. The TLD 600 is capable of detecting gamma and thermal neutron radiation and was employed to check for neutron radiation in the soil. Detectable neutron radiation would indicate the presence of transuranic elements which undergo spontaneous fission.

The response of TLD 600s to thermal neutron exposure is related through the calibration to the response of tissue if tissue were present. Therefore, all thermal neutron exposures are reported in mrads. 


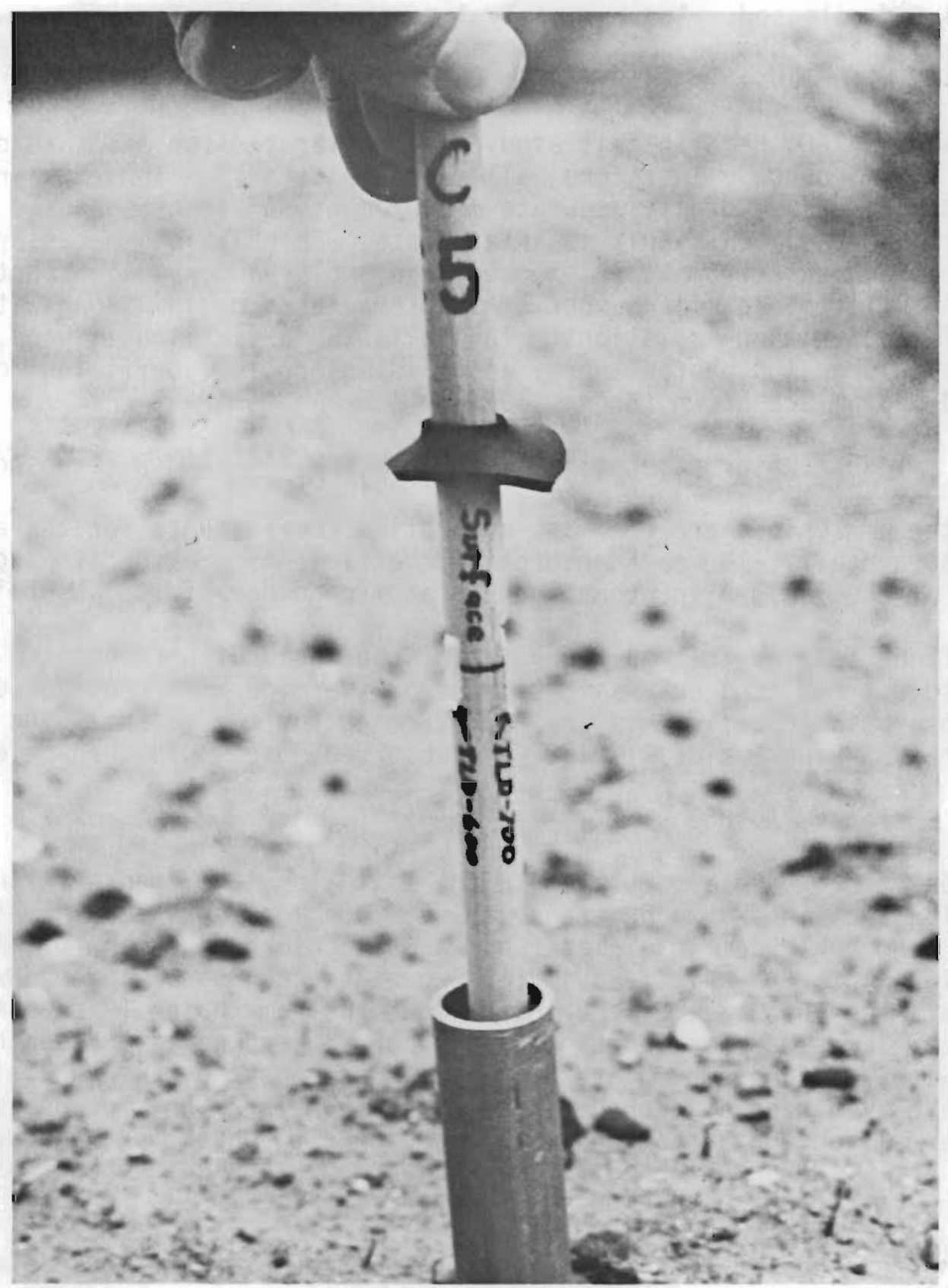

Neg. PNL 77E023-1

FIGURE 4. Dowel Showing Surface Location of Dosimeters Used to Measure Soil Exposure 


\section{RESEARCH AND ANALYSIS}

The trapping effort had four main objectives. The first was to determine species composition of the small mammals living in the vicinity of U-Pond and the two contributing ditches; the second was to quantitatively measure the uptake of nuclides, and the third was to determine the gamma exposure to small mammals inhabiting the radiation zones adjacent to the pond. The fourth part of this study enabled edaphic exposure rates to be checked by placing dosimeters at certain levels in the soil. The following text includes the field work and corresponding analyses.

\section{SPECIES COMPOSITION AND RELATIVE ABUNDANCE}

There were four species of mice trapped at the U-Pond site. They included the Great Basin pocket mouse, Perognathus parvus, deer mouse, Peromyscus maniculatus, house mouse, Mus musculus, and the western harvest mouse, Reithrodontomys megalotis.

The relative abundance of each species varied according to the habitat of each transect. The vegetation on the U-Pond control transect is described as sagebrush-cheatgrass/Sandberg bluegrass type (Daubenmire, 1970; Cline, et al., 1975). The most frequently trapped small mammal on this transect was the pocket mouse with 43 individual animals and second was the deer mouse with 28 individuals (Table 1). The transects along U- and Z-Ditches appear to have vegetation similar to the control transect with the exception of nearby free water and a very limited and narrow riparian zone. The major small mammal species trapped along these transects was the pocket mouse comprising $82 \%$ of the individuals captured at U-Ditch and 69\% at Z-Ditch (Appendix E-1). Deer mice comprised the majority of individuals captured in the riparian vegetation of the Meadow and Forest transects with $37 \%$ and $46 \%$ respectively. Species composition was most diverse at these two transects with all four species represented in both (Table 1).

The control transect located at Rattlesnake Springs was established to correspond with the riparian vegetation transects at U-Pond. It also served as an added control for deer mice to supplement data collected on the control transect near U-Pond. The trapping effort at Rattlesnake Springs yielded 36 deer mice, making it an effective control for this species.

TABLE 1. Total Number of Animals Captured and Percentage of Each Species on U-Pond and Control Transects

\begin{tabular}{|c|c|c|c|c|c|c|c|c|c|c|c|c|}
\hline & \multicolumn{2}{|c|}{$\begin{array}{l}\text { R.S. } \\
\text { Controj (a) }\end{array}$} & \multicolumn{2}{|c|}{$\begin{array}{l}\text { U-Pond } \\
\text { Control }\end{array}$} & \multicolumn{2}{|c|}{ Z-Ditch } & \multicolumn{2}{|c|}{ Meadow } & \multicolumn{2}{|c|}{ U-Ditch } & \multicolumn{2}{|c|}{ Forest } \\
\hline & $n$ & $\%$ & $n$ & $\%$ & $n$ & $\%$ & $n$ & $\%$ & $n$ & $\%$ & $n$ & $\%$ \\
\hline Pocket Mouse & & & 43 & 61 & 45 & 69 & 17 & 23 & 51 & 82 & 6 & 10 \\
\hline Deer Mouse & 36 & 97 & 28 & 39 & 19 & 29 & 28 & 37 & 9 & 15 & 27 & 46 \\
\hline House Mouse & 1 & 3 & & & 1 & 2 & 26 & 35 & 2 & 3 & 21 & 36 \\
\hline Harvest Mouse & & & & & & & 4 & 5 & & & 5 & 8 \\
\hline
\end{tabular}

(a) Rattlesnake Springs Control

n Number of individuals caught

$\%$ Percent of individuals caught on each transect 


\section{RADIOCHEMICAL ANALYSES}

Radiochemical analyses were conducted for both gamma-emitting nuclides and plutonium.

Gamma-Emitting Nuclides

Composite samples representing six tissue types were analyzed for gammaemitting nuclides. The tissues used were fur-skin, liver, kidney, lung, gastrointestinal tract, and muscle-bone. Samples from each of the transects were represented during the three sampling periods.

The most abundant gamma emitter detected from the U-Pond samples was ${ }^{137} \mathrm{Cs}$ (Appendix A). The gamma scan indicated that the next most abundant nuclide in the samples was ${ }^{106} \mathrm{Ru}$. However, this nuclide was represented in only one out of three sampling sessions. The May 1975 sampling session showed ${ }^{106} \mathrm{Ru}$ with an average of $220 \mathrm{pCi} / \mathrm{g}$ dry.

The highest content of ${ }^{137} \mathrm{Cs}$ was found in a house mouse GI tract composite and contained $1600 \pm 82 \mathrm{pCi} / \mathrm{g}$ dry. This sample came from the Z-Ditch transect. The remaining five tissue types from this species on this transect also showed high values, with the lowest being $470 \mathrm{pCi} / \mathrm{g}$ dry. Next in order from the highest to lowest were the western harvest mouse, the deer mouse, and the Great Basin pocket mouse. The harvest mouse was represented in the samples only twice, once in the Meadow and once in the Forest transect. The ${ }^{137} \mathrm{Cs}$ levels, for these samples, however, compared quite closely with those of the house mice from these transects and sampling sessions (Appendix A-1 through A-6).

The deer mice were the most completely represented species and occurred on al1 transects. On three of the transects, the Z-Ditch, Meadow, and the Forest, deer mice were collected during each of the sampling sessions. Upon comparing the three sessions, results from the October session in most cases appears to have higher concentrations than the other two sessions for this mouse. This suggested trend can especially be seen in the muscle-bone sample for deer mice. The replication of this trend in other tissue samples of deer mice corroborates this suggestion. Affirmation of this trend may prove to be very important as an aid to monitoring the uptake of radionuclides by deer mice; however, additional work on the seasonal variations of nuclide uptake by deer mice is needed to confirm this possible trend.

The pocket mouse samples, in contrast, show very little activity from the three transects they represented in this sampling scheme. These transects were the control, Z-Ditch and U-Ditch, all of which contained similar levels of radiocesium.

In a different analysis, mice were randomly taken throughout the year and analyzed as individual animals. The samples were divided into two tissue types: 1) hide, feet and tail, and 2) remaining carcass. In this analysis, levels of 
${ }^{137} \mathrm{Cs}$ for deer mice closely resembled the figures from the composite samples. The locations yielding deer mouse samples for this analysis were again the Z-Ditch, Meadow, and Forest transects. A7though pocket mice were not captured during the first three sampling sessions on the Meadow and Forest transects, they were represented on these transects in this sampling scheme. This time the quantity of cesium detected in pocket mice closely resembled that of the deer mice from the same transects. Two pocket mice from the Meadow had levels exceeding that of the deer mice ranging from 138 to $332 \mathrm{pCi} / \mathrm{g}$ dry as opposed to 8.5 to $265 \mathrm{pCi} / \mathrm{g}$ dry (Appendix A-13).

The gamma scan data from these two sampling schemes show the Meadow and the Forest transects as the areas with the highest levels of radiocesium uptake by the smal1 mammals sampled. Next are the ditches which are represented by deer mice, house mice, and harvest mice. Activity levels in pocket mouse tissues taken from the ditches are not significantly different from those on the control transect. The similarity of the results from individual samples and the composites indicates that combining of like tissues probably did not obscure any high values of individual tissue.

\section{Plutonium Analysis}

Four composite sample types were used for an isotopic plutonium analysis. They were fur-skin, liver, lung, and muscle-bone. The sample groups used were selected from the gamma scan results as the ones containing ${ }^{13}{ }^{7} \mathrm{Cs}$ activity. Also, an effort was made to represent al1 transects at least once.

Results from the analyses indicated that the amount of plutonium being taken up by small mammals was very low. Figures $5 a, 5 b, 5 c$, and $5 d$ show concentrations for the four species trapped. The highest concentrations came from house mice living in the Meadow area and along the Z-19 Ditch (Figure 5a). A composite fur-skin sample from six house mice living in the Meadow yielded the highest value with $2.03 \mathrm{pCi} 239-240 \mathrm{Pu} / \mathrm{g}$ dry. Samples representing the other three species in this analys is showed very low values for plutonium and americium of $\leq 0.5 \mathrm{pCi} / \mathrm{g}$ dry. In another analysis for plutonium, whole mice were analyzed using deer mice from Z-19 Ditch and house mice from the Meadow. In this analysis the samples were tested for $238 \mathrm{Pu}$ and $239+240 \mathrm{Pu}$. The results for ${ }^{238} \mathrm{Pu}$ showed levels very near background but for $239+240 \mathrm{Pu}$ the deer mice from Z-19 exhibited levels that appeared slightly above the control values which average $0.98 \mathrm{pCi} / \mathrm{g}$ dry (Table 2).

The data from these analyses indicate that of the four species of mice tested, the house mouse, the deer mouse, and the harvest mouse have the greatest opportunity for uptake of radionuclides at the U-Pond site.

Food Habits

The most probable explanation for the higher concentrations of the above three species may be related to their food habits and environmental or habitat preference. The omnivorous deer mouse is an opportunistic feeder taking advantage of whatever food is available (Williams, 1959; Flake, 1973; Kritzman, 1974; 

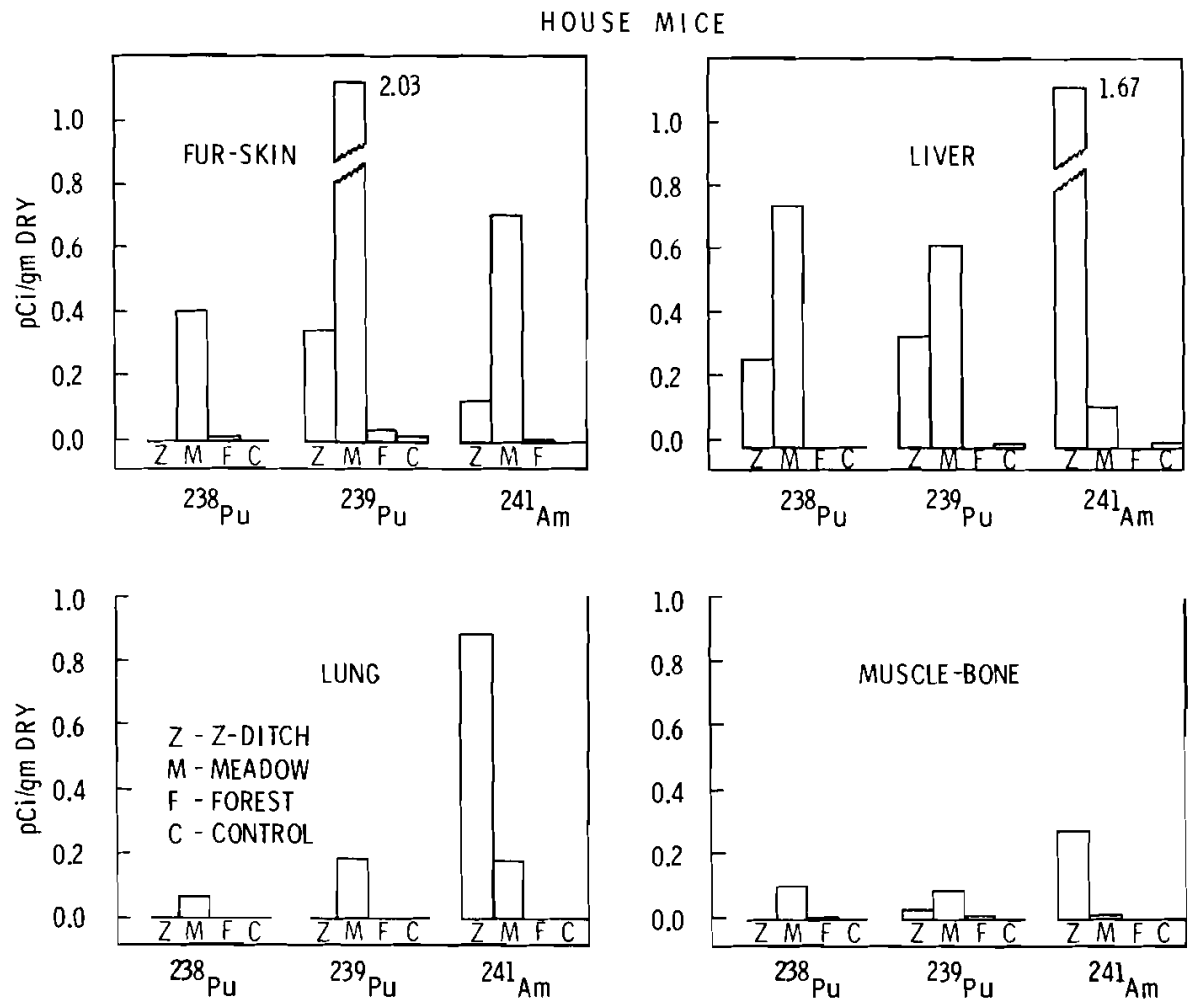

FIGURE 5a. Concentrations of Plutonium and Americium in Composite House Mouse Samples

POCKET MICE
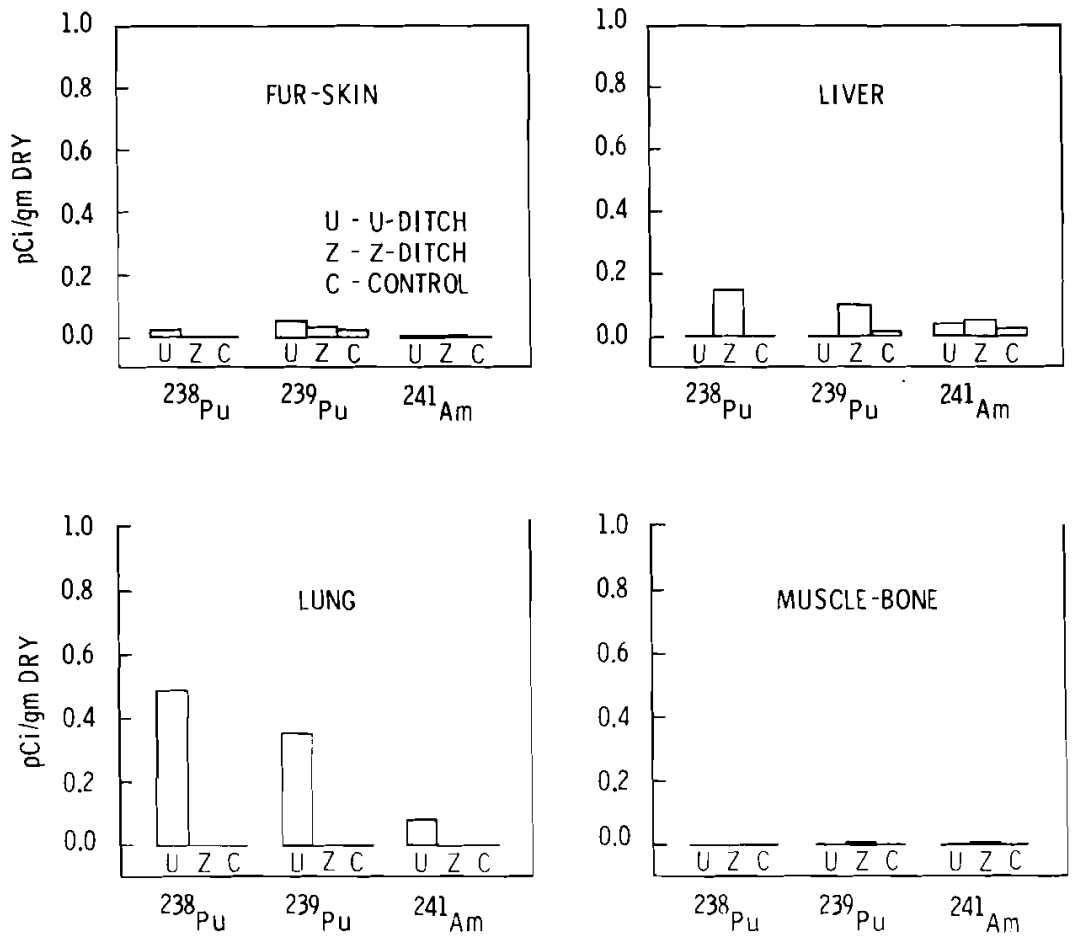

FIGURE 5b. Concentrations of Plutonium and Americium in Composite Pocket Mouse Samples 

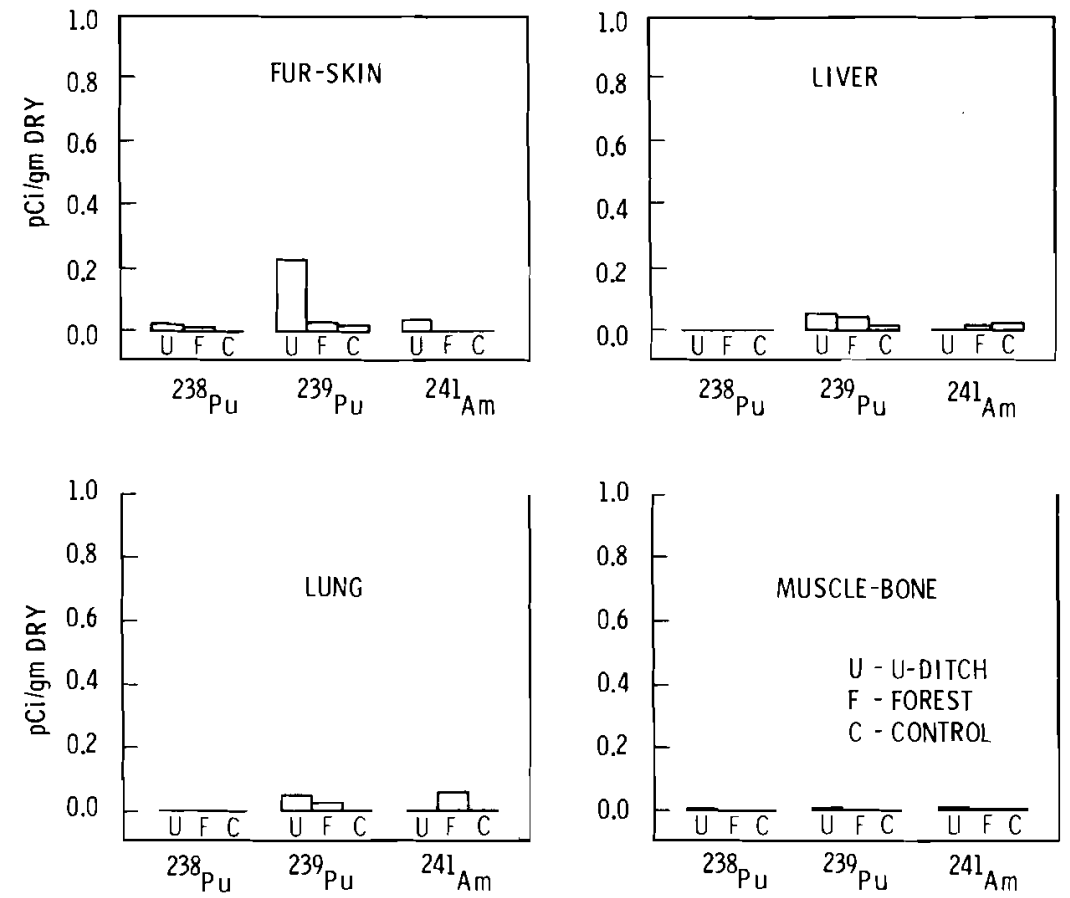

FIGURE 5c. Concentrations of Plutonium and Americium in Composite Deer Mouse Samples
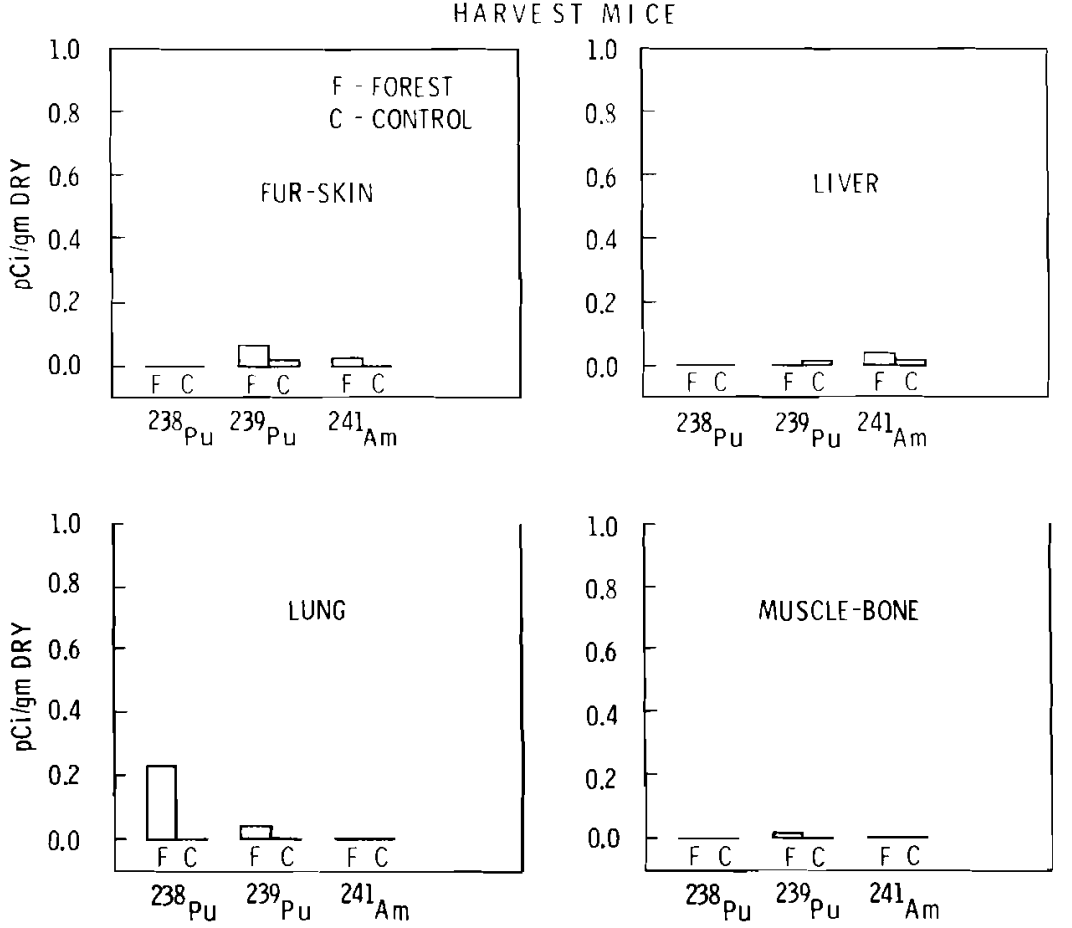

FIGURE 5d. Concentrations of Plutonium and Americium in Composite Harvest Mouse Samples 
TABLE 2. U-Pond Plutonium Analysis on Whole Mice

\begin{tabular}{|c|c|c|c|}
\hline Species & $\underline{\bar{x}}$ Dry wt g & $\begin{array}{c}238 \mathrm{Pu} \\
\bar{x} \mathrm{pCi} / \mathrm{g} \text { dry }\end{array}$ & $\begin{array}{c}239+240 \mathrm{Pu} \\
\bar{x} \mathrm{pCi} / \mathrm{g} \mathrm{dry} \\
\end{array}$ \\
\hline $\begin{array}{c}\text { Deer Mouse } \\
\text { Z-Ditch } \\
n=3\end{array}$ & 4.5 & $0.10(0.005)$ & $0.98(0.05)$ \\
\hline $\begin{array}{c}\text { Control } \\
n=1\end{array}$ & 5.0 & $0.13(0.006)$ & $0.12(0.006)$ \\
\hline $\begin{array}{l}\text { House Mouse } \\
\text { Meadow } \\
n=2\end{array}$ & 4.8 & $0.03(0.002)$ & $0.07(0.003)$ \\
\hline $\begin{array}{c}\text { Control } \\
n=1\end{array}$ & 3.8 & $0.03(0.002)$ & $0.06(0.003)$ \\
\hline
\end{tabular}

Johnson, 1975). The presence of free water and an abundance of riparian vegetation enhances the availability of food for this mouse. MacMillen (1964) showed that deer mice, when fed a diet of only dry seeds, had a mean time till death of about 20 days. This supports the theory that they must satisfy their water requirements by eating green vegetation, arthropods, or by drinking free water. The deer mice living at U-Pond most likely do all three.

The house mouse is likewise an omnivorous feeder, eating seeds, fruits, vegetables, meat and arthropods (Ingles, 1965; Brooks, 1973). This mouse also seeks the lush vegetation and free water of the ditches and pond to satisfy its water requirements. The western harvest mouse also selects a habitat with dense vegetation, especially grasses near water. The major food items are seeds, succulent stems, fruits, and insects (Hall and Kelson, 1959; Ingles, 1965; Burt and Grossenheider, 1976). In an arid environment, U-Pond provides an ideal habitat for this mouse.

The pocket mouse, on the other hand is primarily a granivore and can subsist solely on a diet of dry seeds (Schmidt-Nielson et al., 1948; Kritzman, 1974). This species does not need free water but occasionally eats green vegetation during the spring months when available. Pocket mice also prefer the dry sandy soil of the surrounding noncontaminated desert for constructing their deep and elaborate burrow systems (Scheffer, 1938; Ha11, 1946). This probably explains the low activity levels observed in pocket mice at the U-Pond site.

\section{GAMMA EXPOSURES TO SMALL MAMMALS}

Small mammals associated with the U-Pond study site were also investigated for external gamma exposure. The procedure involved surgically implanting thermoluminescent dosimeters (TLDs) subcutaneously and releasing the animal to be caught at a later date. The technique proved very successful; overa11, $49 \%$ of the TLDs implanted were recovered. 
Dosimeters recovered from animals living in the Meadow area exhibited the highest exposures (Figure 6). The three species represented there were, from highest dose to lowest, the house mouse, pocket mouse, and deer mouse with mean doses of $55 \mathrm{R} / \mathrm{yr}, 43 \mathrm{R} / \mathrm{yr}$, and $21 \mathrm{R} / \mathrm{yr}$, respectively (Table 3 ). The Forest transect was also represented by all three species and likewise showed significant exposures above background. The Z-Ditch was the only other transect to show animals receiving significant exposures. The animals being exposed on this transect were deer mice. Pocket mice were also represented on Z Transect claiming more recaptures than any other species or location. Thirty-two dosimeters were recovered giving a mean dose of $0.14 \mathrm{R} / \mathrm{yr}$. This figure agrees with the pocket mouse exposures on the control transect of $0.09 \mathrm{R} / \mathrm{yr}$. The exposure data from U-Ditch were represented by only one species, the pocket mouse, whose doses were slightly higher than the control with $0.35 \mathrm{R} / \mathrm{yr}$. Deer mice from both control transects had identical exposures of $0.07 \mathrm{R} / \mathrm{yr}$.

Dosimeters were not recovered from house mice on $Z$ Transect, $U$ Transect, or the control transects and deer mice on $U$ Transect. Capture frequencies for house mice are very low even in an area of higher density. This is attributed to the seeming sixth sense of house mice for shying away from traps (Brooks, 1973) along with a probable low density. Personal experience has shown that harvest mice are very difficult to trap and even more difficult to retrap. Although six animals were successfully implanted with TLD packets, there were no recaptures and, consequent1y, no exposure rate data were obtained. The number of deer mice captured along $U$ Trench was also very low throughout the study period.

From the dosimeter data gathered in this study, it becomes apparent that mice living in the Meadow and Forest transects received the most significant gamma exposure. This can be attributed to the fact that at one time the pond was much larger, encompassing these areas. When the pond receded it left sediments containing radionuclides exposed and readily available to terrestrial plants and animals.

The effect from the highest exposure rate recorded at $U$-Pond $(1.47 \mathrm{R} / \mathrm{Wk}$ to a pocket mouse; see Appendix $C-5$ ) would probably be very slight or even immeasurable. A decrease in the number of circulating lymphocytes in the blood is a very sensitive measure of radiation exposure. Acute doses of 5-25 rads can cause a drop in the number of these cells in rats (Casarett, 1968). However, with a maximum chronic dose of approximately 1.4 rad per week, a decrease in lymphocytes may not be detectable. No obvious abnormalities were noticed in mice during this study. Further investigation of histopathological changes is needed to determine the effects of very low chronic exposures to U-Pond mice.

\section{EDAPHIC EXPOSURE RATES}

Dosimeters placed in the soil along the trapping transects revealed that the location of the strongest gamma exposures is the top decimeter of soil (Figure 7). The highest exposures came from the Meadow transect with a mean of $75 \mathrm{R} / \mathrm{yr}$ in the first decimeter. The levels of exposure diminished rapidly with depth, going down to $1.5 \mathrm{R} / \mathrm{yr}$ at $5 \mathrm{dm}$ (Table 4 ). This trend is consistent 


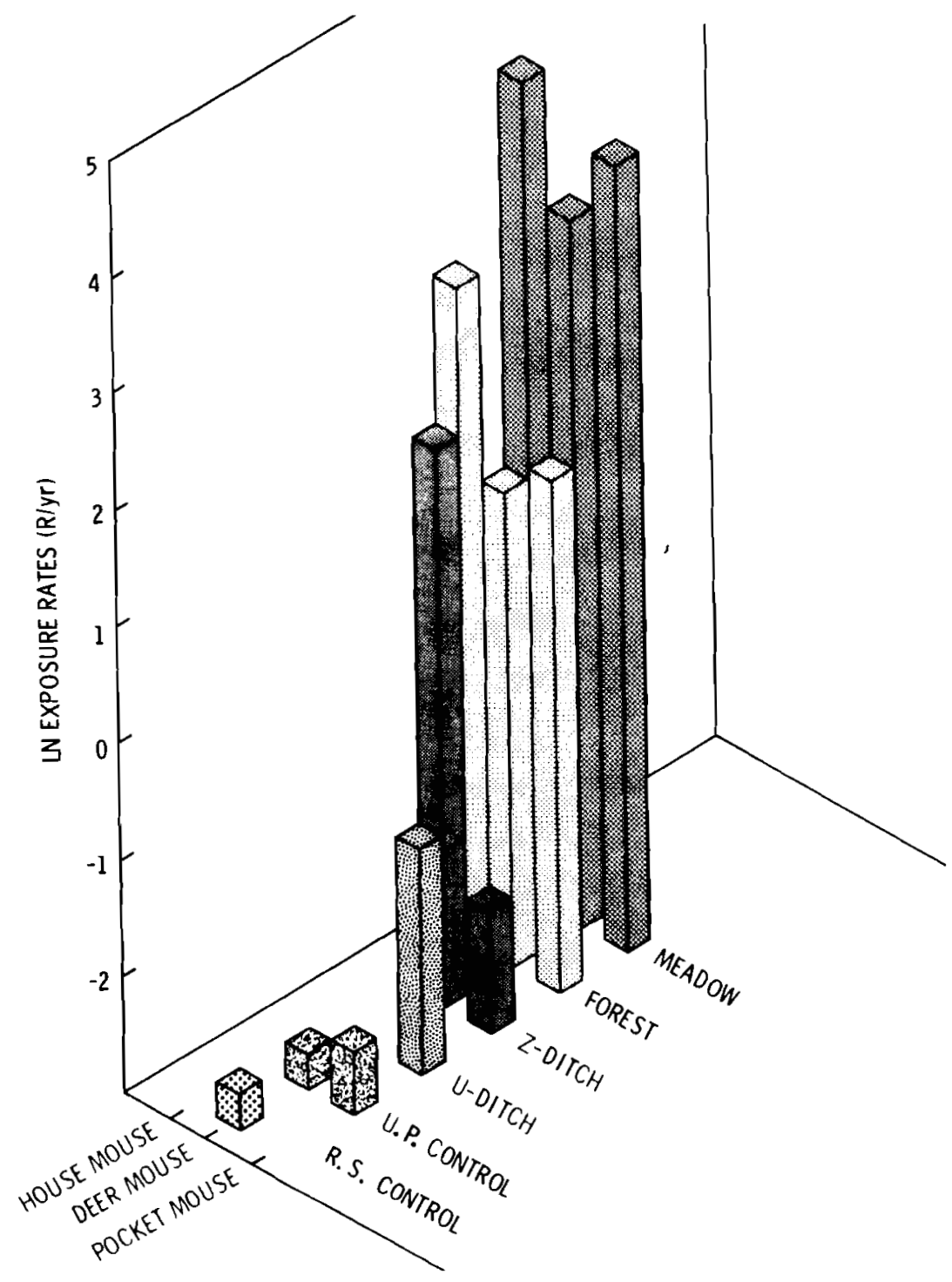

FIGURE 6. Gamma Exposure to Mice Living Along U-Pond and Control Transects

TABLE 3. Mean Gamma Exposures to U-Pond Mice in R/yr

R. S. Control (a) Pocket Mouse U. P. Control R/yr \pm S.E. Z-Ditch U-Ditch Forest Meadow
$0.09 \pm 0.005$
$0.14 \pm 0.01$
$0.35 \pm 0.11$
$4.02 \pm 2.5$
$42.6 \pm 7.32$

$$
\text { Deer Mouse }
$$
House Mouse R/yr \pm S.E. $\quad R / y r \pm S . E$.

(a) Rattlesnake Springs Control. 


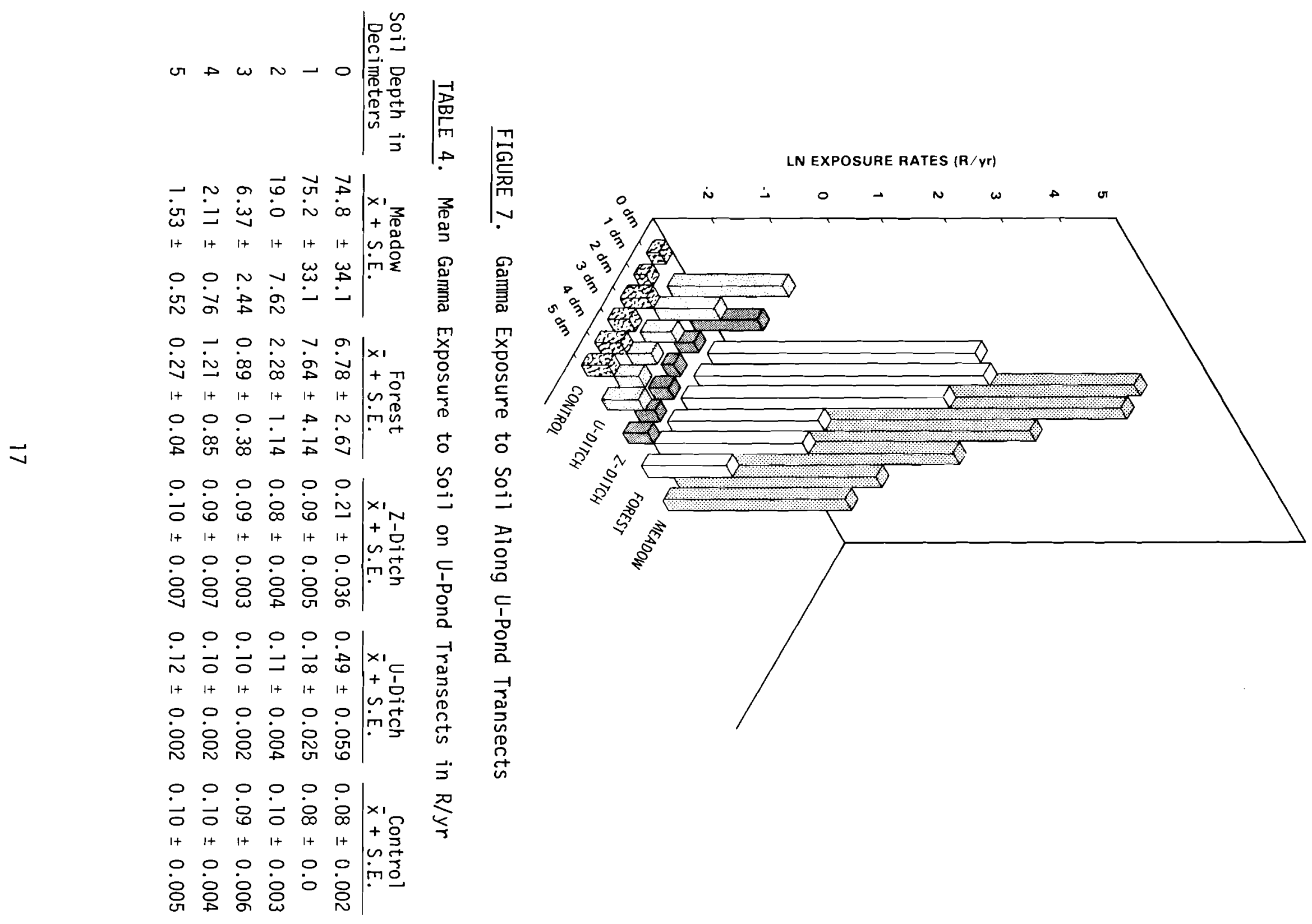


on a11 the transects at U-Pond. The control transect shows the exposure rate to be consistent from the surface to $5 \mathrm{dm}$. The higher exposure rates to the soil in the Meadow and Forest areas concur with the higher exposure levels of the animals living on these areas.

\section{Neutron Exposure in the Soil}

U-Pond historically has received low-level releases of plutonium processing wastes along with many other transuranics at marginally detectable levels (Emery and Garland, 1974). The pond receives plutonium processing effluents from the 234-5 plant via the Z-19 Ditch. Although processing wastes continuously flow into the ditch, releases of plutonium are usually low level and on an intermittent basis. For this reason, dosimeters capable of detecting thermal neutron radiation were incorporated in the soil dosimeter probes along the transects.

The Meadow area showed the highest neutron exposure again in the first decimeter of soil with an average of $37 \mathrm{mrad} / \mathrm{yr}$ (Table 5). The forest transect showed quite a reduced dose from the Meadow with $4.8 \mathrm{mrad} / \mathrm{yr}$ at $1 \mathrm{dm}$ and again tapering down with depth. The Z-19 Ditch was the only other location sampled that showed a neutron exposure. In this case, however, the trend of highest to lowest from the surface down was somewhat reversed. The highest average level detected here was $7.8 \mathrm{mrad} / \mathrm{yr}$ and was at $4 \mathrm{dm}$. The lowest was $1.9 \mathrm{mrad} / \mathrm{yr}$ at $1 \mathrm{dm}$ and the surface. This reverse trend is probably a function of the dosimeter location near the ditch. On this transect, the aluminum tubing containing the dosimeter was placed halfway down the slope of the ditch. This made the bottom locations on the dowel closer to the level of water in the ditch (Figure 8). The doses along U-14 Ditch and the control transect were similar at all depths, indicating background exposures.

TABLE 5. Mean Neutron Exposure to Soil on U-Pond in $\mathrm{mrad} / \mathrm{yr}$

\begin{tabular}{|c|c|c|c|c|c|c|}
\hline $\begin{array}{l}\text { Soil Depth } \\
\text { in Decimeters }\end{array}$ & $\begin{array}{r}\text { Mead } \\
\bar{x} \pm S \\
\end{array}$ & $\begin{array}{l}\text { dow } \\
\text { S.E. }\end{array}$ & $\begin{array}{l}\text { Forest } \\
\bar{x} \pm \text { S.E. }\end{array}$ & $\begin{array}{c}Z \text { Transect } \\
\bar{x} \pm \text { S.E. } \\
\end{array}$ & $\begin{array}{c}\text { U Transect } \\
\bar{x} \pm \text { S.E. }\end{array}$ & $\begin{array}{c}\text { Control } \\
\bar{x} \pm \text { S.E. }\end{array}$ \\
\hline 0 & $37.1 \pm$ & +16.2 & $4.1 \pm 1.58$ & $1.87 \pm 1.25$ & $0.48 \pm 0.02$ & $0.26 \pm 0.0$ \\
\hline 1 & 35.8 & \pm 18.7 & $4.8 \pm 2.69$ & $1.87 \pm 1.25$ & $0.27 \pm 0.02$ & $0.30 \pm 0.01$ \\
\hline 2 & 12.0 & 5.63 & $1.52 \pm 0.63$ & $4.37 \pm 1.81$ & $0.32 \pm 0.02$ & $0.31 \pm 0.02$ \\
\hline 3 & $3.64 \pm$ & 1.29 & $0.63 \pm 0.15$ & $2.50 \pm 1.53$ & $0.31 \pm 0.02$ & $0.32 \pm 0.02$ \\
\hline 4 & $1.17 \pm$ & 0.35 & $0.34 \pm 0.02$ & $7.80 \pm 5.27$ & $0.31 \pm 0.02$ & $0.31 \pm 0.02$ \\
\hline 5 & $0.86 \pm$ & 0.37 & $0.36 \pm 0.03$ & $6.25 \pm 2.84$ & $0.33 \pm 0.01$ & $0.33 \pm 0.01$ \\
\hline
\end{tabular}




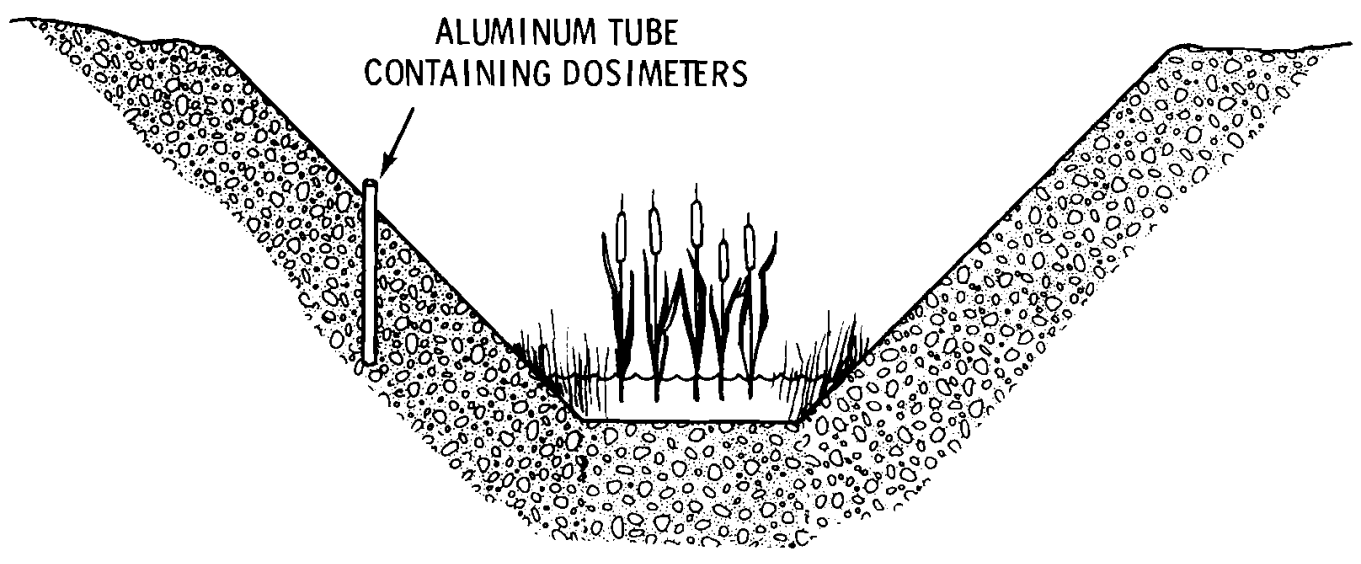

FIGURE 8. Cross Section of Z-19 Ditch Showing Location of Soil Dosimeter Probes 


\section{CONCLUSIONS}

Trapping results along with the radiochemical analyses indicate that the areas of most concern at U-Pond were the Z-19 Ditch and the riparian zone associated with the pond. All species of mice captured in these areas (except poc-

ket mice along Z-Ditch) accumulated concentrations of radiocesium significantly above background.

The number of individuals representing each species on a transect appeared to vary according to habitat preference. Pocket mice preferred the noncontaminated sagebrush-cheatgrass habitat adjacent to the ditches over the riparian habitat surrounding the pond, as indicated by trapping results. Thus, the fewer numbers of this species living near the pond reduced the transfer potential for pocket mice. House mice and deer mice preferred the denser vegetation around the pond and thus pose a greater threat for biological transfer due to their food habits and greater numbers in this area. The potential for biological transfer of radionuclides to a small mammal species and up through the food chain is proportional to the number of individuals of that species present and the availability of radionuclides in an area. Further information should be gathered to determine the origin of the radionuclide concentrations in these animals. The biological transfer pathway of radionuclides to mice could be further examined by diet analysis. A follow-up on the results could include a radiochemical analysis of the food items detected. The emphasis of waste management at this site could then be directed toward the primary biological transfer organisms.

The radiation exposure data from thermoluminescent dosimeter (TLD) implants showed the highest exposures to animals living along the transects near the pond. The three species for which data were obtained (house mice, deer mice and pocket mice) each had exposures above background. This trend agrees with the radiochemical analysis data from these areas. Animals living along the Meadow and Forest transects appear to be accumulating above background concentrations of radionuclides and external radiation exposures. This also appears to be true for mice living along the two ditches, but to a lesser degree. In most instances the values from the ditches appear only slightly above background.

Results from dosimeters placed in the soil along the trapping transects showed the greatest exposure in the surface decimeter of soil. The transects with the highest exposure were those closest to the pond. This means that the surface decimeter of soil near the pond probably has the highest concentrations of radionuclides. This low level contamination could be readily available to vegetation which provides a food base for the inhabiting mice. It could also account for the higher exposure rates to mice 1 iving near the pond.

Deer mice captured along Z-19 Ditch received higher exposure rates than corresponding soil dosimeters. This is due to the location of the soil dosimeters along one bank of the ditch. These higher exposure rates indicate that the deer mice preferred the dense vegetation near the bottom of the ditch where higher exposure rates exist. The water and lush emergent vegetation covering the ditch provided a good habitat for deer mice. 


\section{LITERATURE CITED}

Arena, V. 1971. Ionizing Radiation and Life. C. V. Mosby, St. Louis, M0.

Brooks, J. E. 1973. A Review of Commensal Rodents and Their Control. New York State Department of Health, Bureau of Rodent Control, Albany, NY, pp. 405-453.

Burt, W. H., and R. P. Grossenheider. 1976. A Field Guide to the Mammals. Houghton-Mifflin Company, Boston, MA.

Casarett, A. P. 1968. Radiation Biology. Prentice-Ha11, Inc. Englewood Cliffs, NJ.

Cline, J. F., D. W. Uresk, and W. H. Rickard. 1975. Characterization of Plant Communities Adjacent to the B-C Cribs Controlled Area and RED0X Pond Areas on the 200 Area Plateau. BNWL-1916. Battelle, Pacific Northwest Laboratories, Richland, WA.

Daubenmire, 1970. Steppe vegetation of Washington. Wash. Agric. Exp. Tech. 62, $131 \mathrm{pp}$.

Emery, R. M., and T. R. Garland. 1974. The Ecological Behavior of Plutonium and Americium in a Freshwater Ecosystem: Phase II. BNWL-1879. Battelle, Pacific Northwest Laboratories, Richland, WA.

Energy Research and Development Administration. 1975. Final Environmental Statement. 2 Vols. ERDA-1538, Waste Management Operations, Hanford Reservation, Richland, WA.

Fitzner, R. E., and W. H. Rickard. 1975. Avifauna of Waste Ponds, ERDA Hanford Reservation, Benton County, Washington. BNWL-1885. Battelle, Pacific Northwest Laboratories, Richland, WA.

Flake, L. D. 1973. Food habits of four species of rodents on a short-grass prairie in Colorado. J. Mammal. 54:636-47.

Hal1, E. R. 1946. Mammals of Nevada. Univ. Calif. Press, Berkeley and Los Angeles.

Hall, E. R., and K. R. Kelson. 1959. The Mammals of North America. Ronald Press Co., New York.

Ingles G. L. 1965. Mammals of the Pacific States. Stanford Univ. Press, Stanford, CA. 
Johnson, M. K. 1975. Interspecific Association of Peromyscus maniculatus, Perognathus parvus, and Spermophizus townsendi on the Arid Lands Ecology Reserve Examined by Diet Overlap and Related Data. BNWL-1929. Battelle, Pacific Northwest Laboratories, Richland, WA, 50 pp.

Kritzman, E. G. 1974. Ecological relationships of Peromyscus maniculatus and Perognathus parvus in eastern Washington. J. Mamma 1. 55:172-88.

MacMillen, R. E. 1964. Population ecology, water relations, and social behavior of a southern California semi-desert rodent fauna, Univ. California Publ. Zool. 71:1-66.

National Bureau of Standards. 1964. Physical Aspects of Irradiation. NBS Handbook No. 85. U.S. Government Printing Office, Washington, DC, p. 3.

Scheffer, T. H. 1938. Pocket mice of Washington and Oregon. U.S.D.A. Tech. Bulletin 608.

Schmidt-Nielsen, B., D. Schmidt-Nielsen, A. Brokaw, and H. Schneiderman. 1948. Water conservation in desert rodents. J. Coll. Comp. Physiol. 32: $331-360$.

Williams, 0. 1959. Food habits of the deer mouse. J. Mammal. 40:415-19. 


\section{APPENDIX A}

DETECTABLE GAMMA-EMITTING NUCL.IDES 
TABLE A.1. Composite Sample Using Like Tissues from Two or More Animals of Same Species, $\mathrm{pCi}{ }^{137} \mathrm{Cs} / \mathrm{g}$ Dry

\section{A.1.1 Fur-Skin Samples}

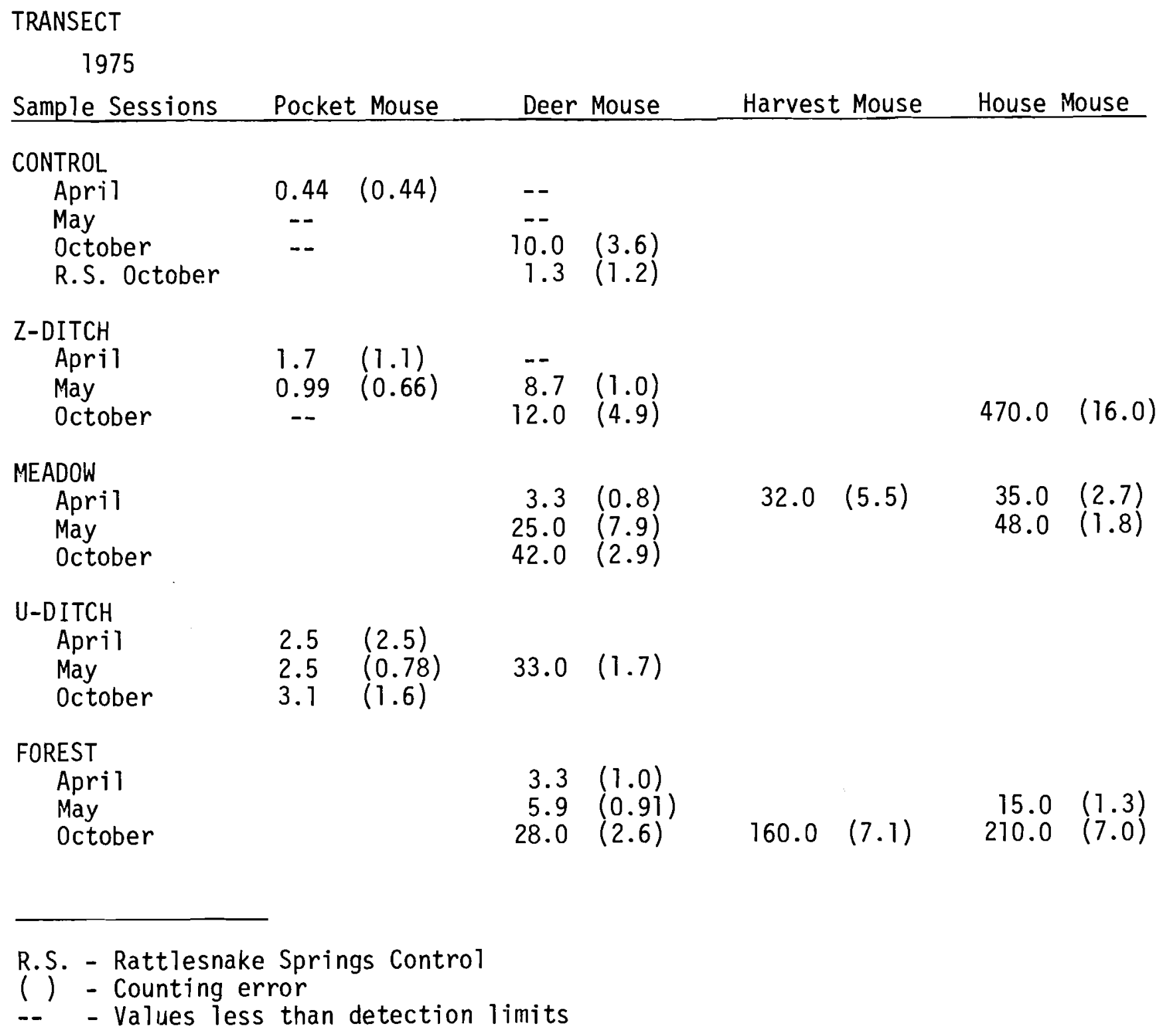


TABLE A.1. (Continued)

A.1.2 Liver Samples

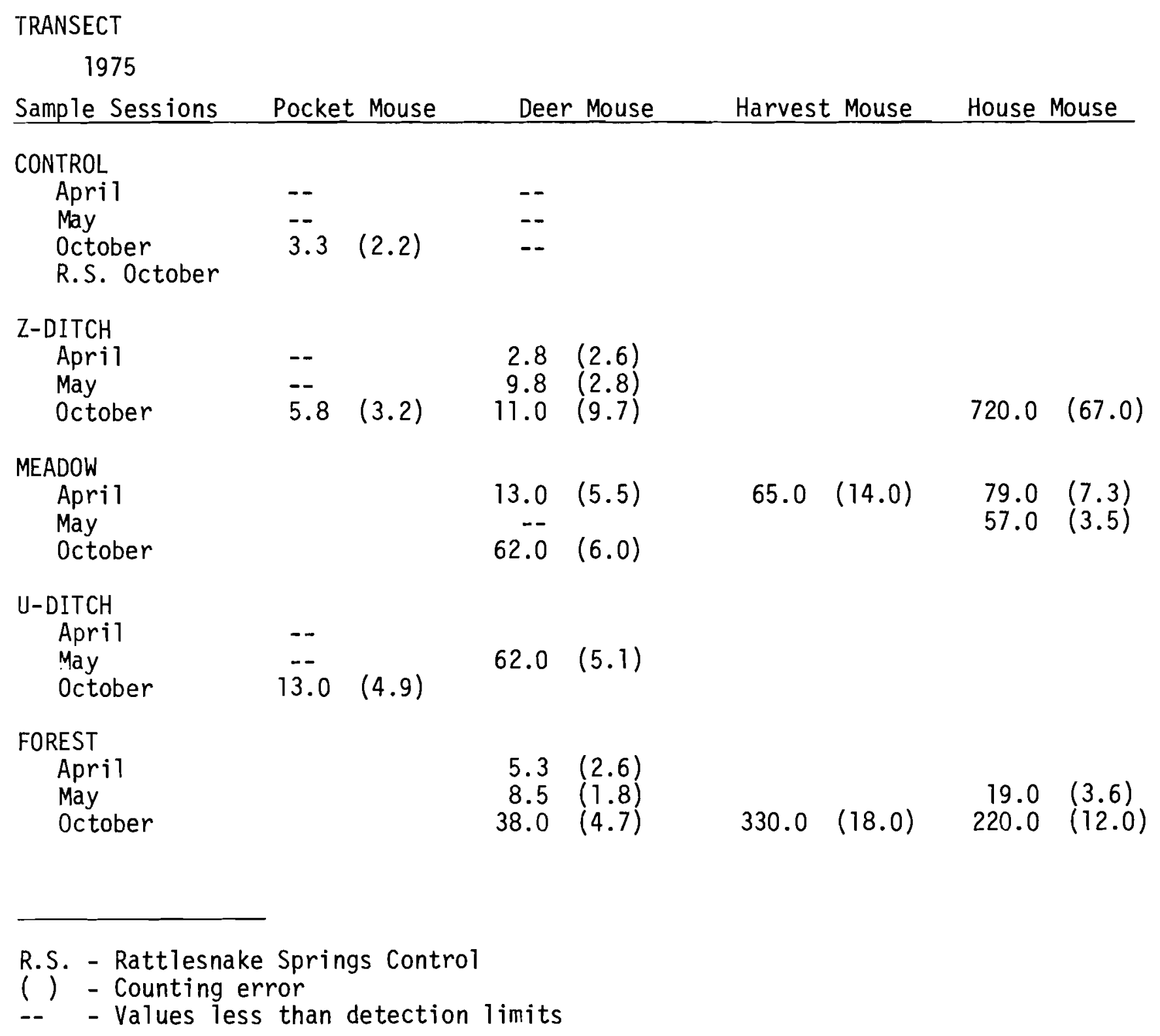

FOREST

April

May

October

$$
\begin{array}{rr}
5.3 & (2.6) \\
8.5 & (1.8) \\
38.0 & (4.7)
\end{array}
$$

$330.0 \quad(18.0)$

$\begin{aligned} 19.0 & (3.6) \\ 220.0 & (12.0)\end{aligned}$

R.S. - Rattlesnake Springs Control

( ) - Counting error

-- - Values less than detection limits 
TABLE A.1. (Continued)

\section{A.1.3 Kidney Samples}

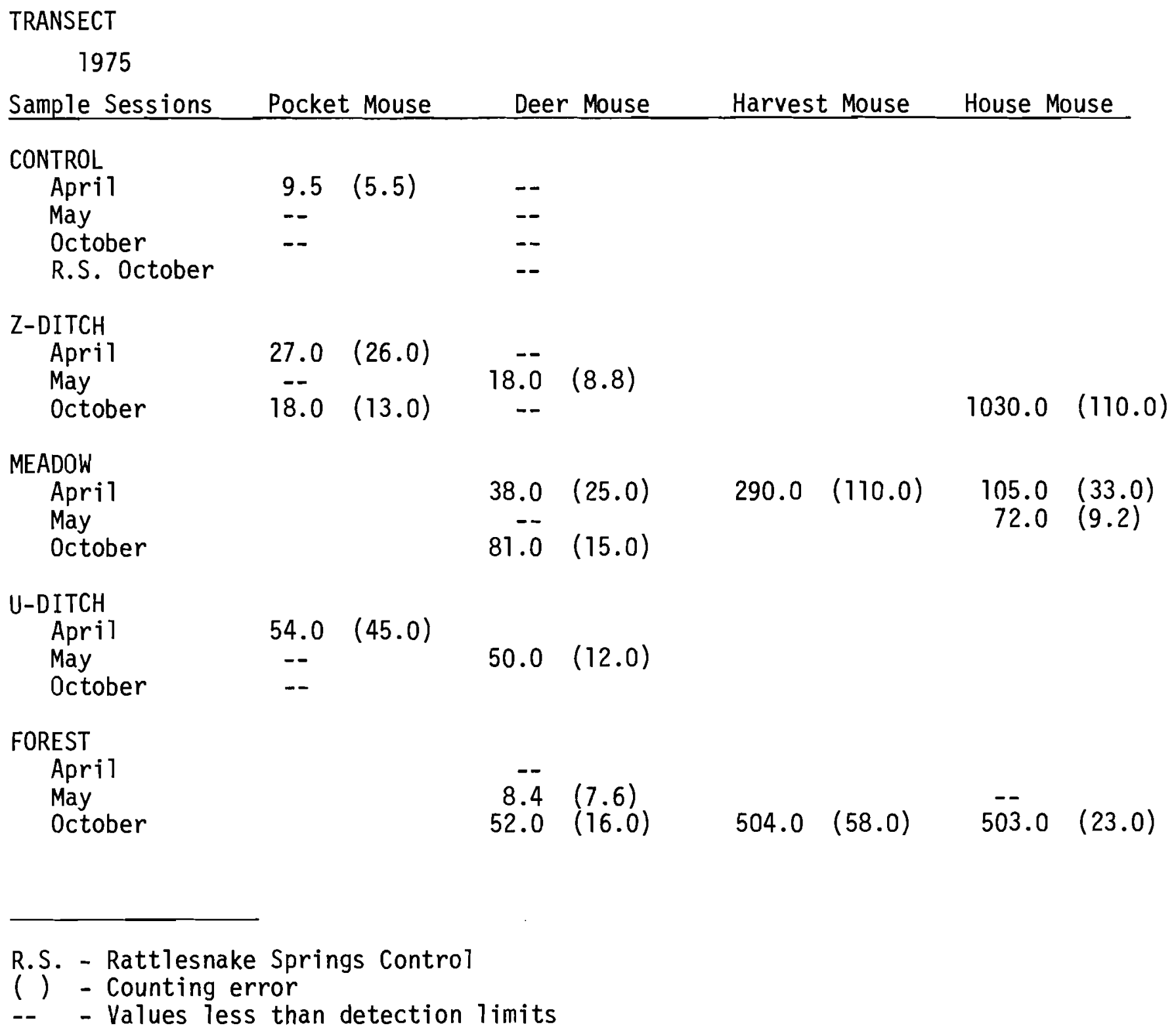

R.S. - Rattlesnake Springs Control

( ) - Counting error

-- - Values less than detection limits 
TABLE A.1. (Continued)

A.1.4 Lung Samples

TRANSECT

1975

Sample Sessions

Pocket Mouse

Deer Mouse

Harvest Mouse

House Mouse

CONTROL

April

May

October

R.S. October

$\begin{array}{cccc}-- & & 124.0 & (80.0) \\ \overline{15.0} & (9.1) & \overline{-} & \\ & & 45.0 & (24.0)\end{array}$

Z-DITCH

Apri1

May

October

$\begin{array}{ll}-- & -- \\ -- & 12.0\end{array}$

(8.8)

MEADOW

April

May

October

$--$

$96.0(18.0)$

U-DITCH

April

May

October

FOREST

April

May

october

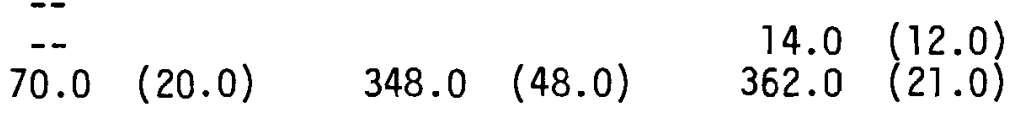

R.S. - Rattlesnake Springs Control

() - Counting error

-. - Values less than detection limits 
TABLE A.1. (Continued)

A.1.5 GI Tract Samples

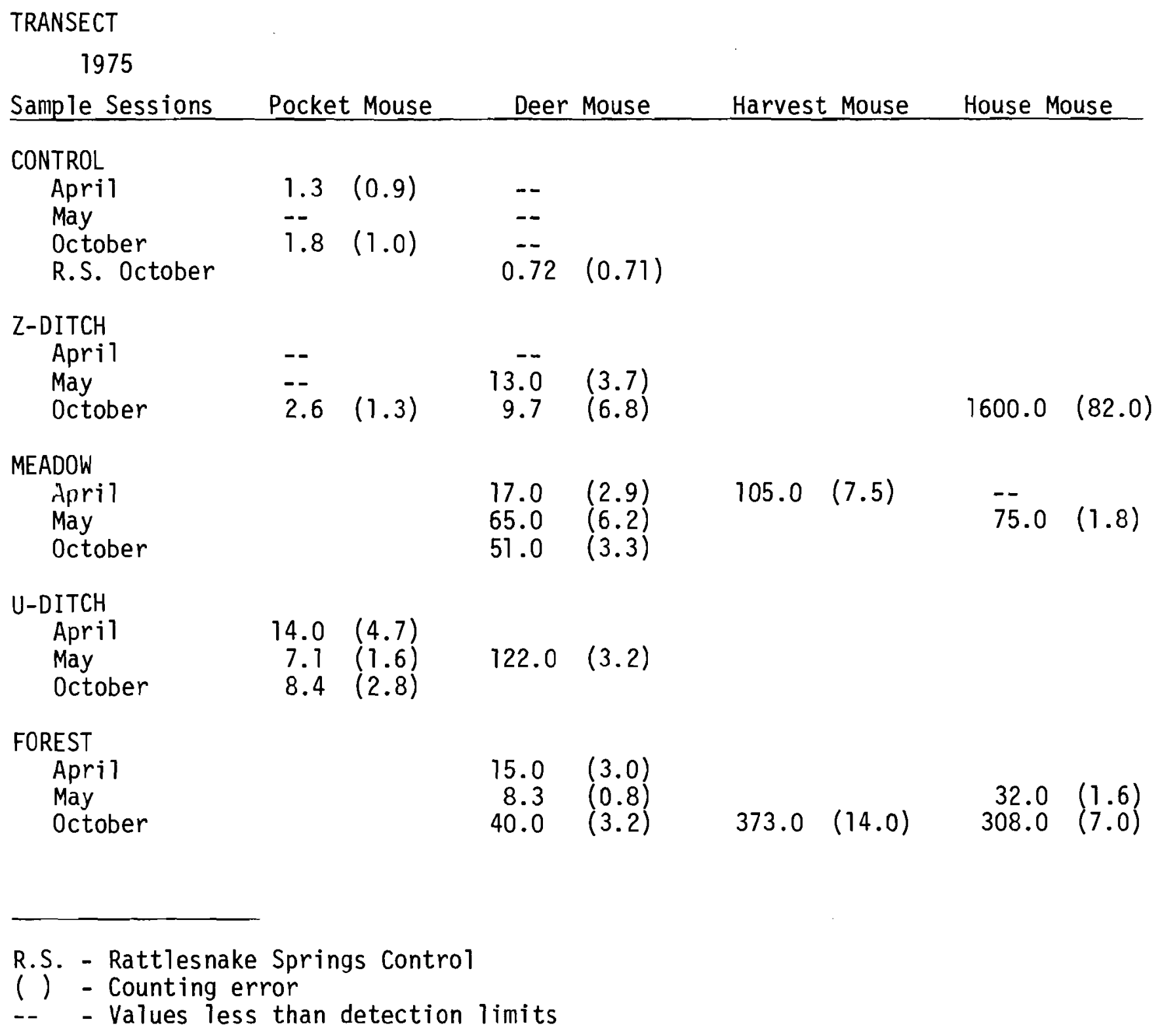


TABLE A.1. (Continued)

A.1.6 Muscle-Bone Samples

\section{TRANSECT}

1975

Sample Sessions

Pocket Mouse

Deer Mouse

Harvest Mouse

House Mouse

CONTROL

$\begin{array}{lcccc}\text { April } & 0.53 & (0.25) & -- & \\ \text { May } & -- & & 0.54 & (0.40) \\ \text { October } & 0.67 & (0.52) & -- & \\ \text { R.S. October } & & & -- & \end{array}$

Z-DITCH

April

May

$\begin{array}{ccc}-- & 0.78 & (0.70) \\ -- & 15.0 & (0.71) \\ -- & 23.0 & (2.2)\end{array}$

$886.0 \quad(34.0)$

MEADOW

Apri 1

May

October

$\begin{array}{ll}28.0 & (1.7) \\ 44.0 & (16.0) \\ 87.0 & (2.7)\end{array}$

$73.0 \quad(6.8)$

$160.0 \quad(4.8)$

$87.0 \quad(2.7)$

U-DITCH

Apri 1

May

October

$+-$

$\begin{array}{ll}5.2 & (0.5) \\ 8.2 & (1.0)\end{array}$

68.0

(2.2)

FOREST

April

May

October

$8.2 \quad(1.0)$

$\begin{array}{ll}15.0 & (1.1) \\ 10.0 & (0.55) \\ 67.0 & (2.6)\end{array}$

361.0

$20.0 \quad(0.8)$

$394.0 \quad(14.0)$

R.S. - Rattlesnake Springs Control

( ) - Counting error

-- - Values less than detection limits 
A.2. Composite Samples Other Than ${ }^{137} \mathrm{Cs}$,
$\mathrm{pC} i / g$ Dry

A.2.1 Sampling Period 9-10 April '75

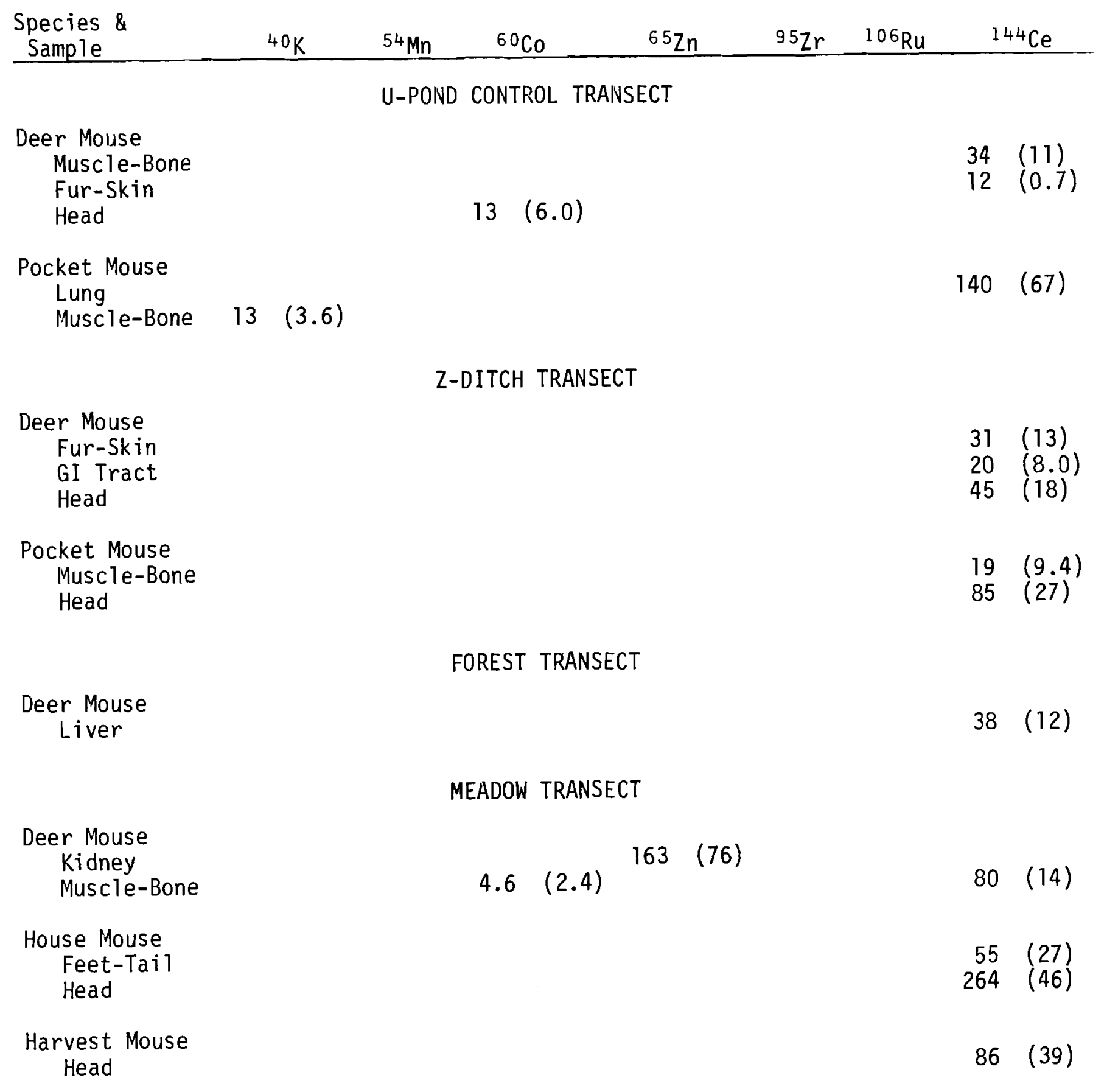


TABLE A.2. (Continued)

\section{A.2.2 Sampling Period 6-7 May '75}

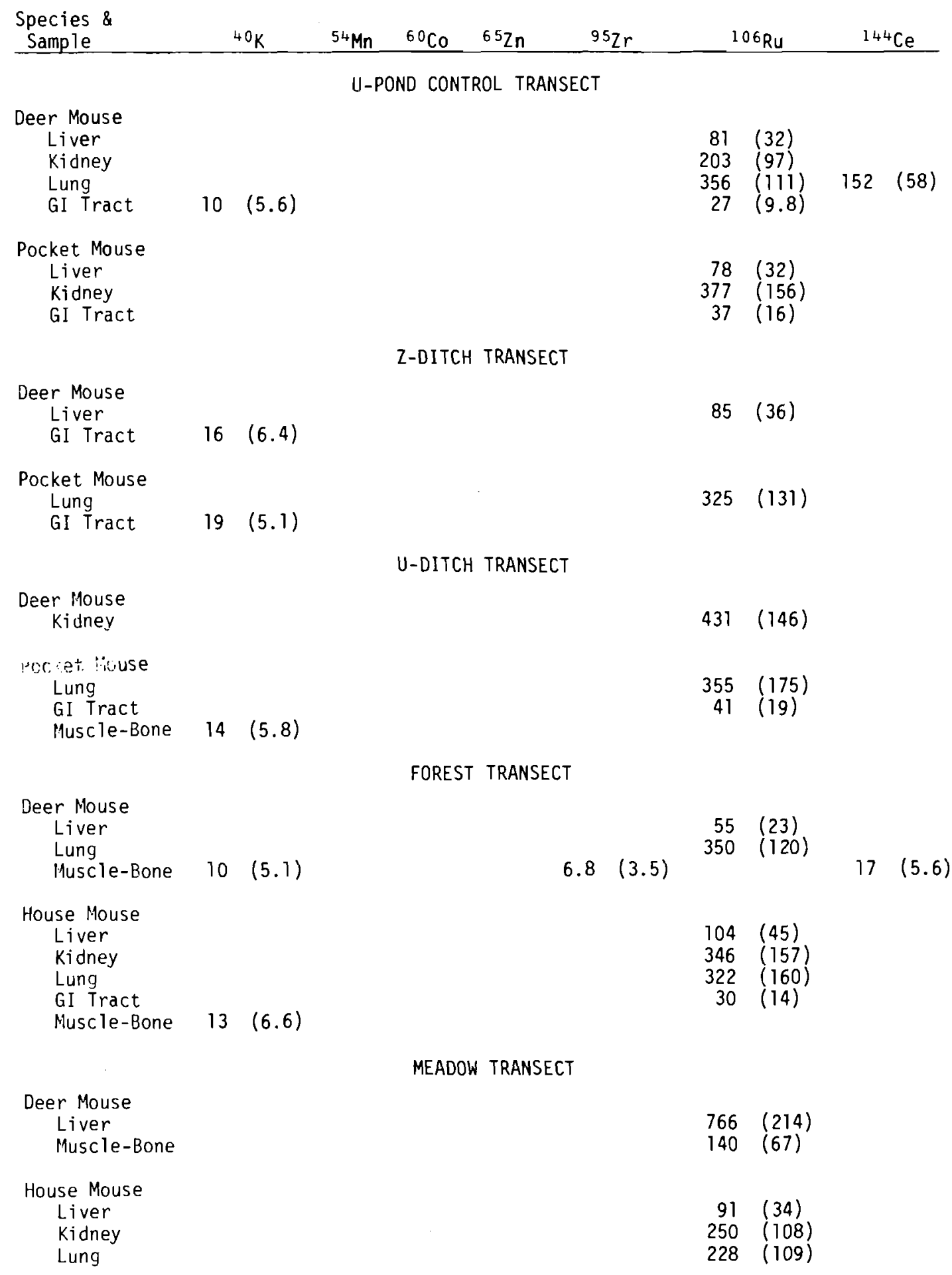


TABLE A.2. (Continued)

\section{A.2.3 Sampling Period 23-24 October ' 75}

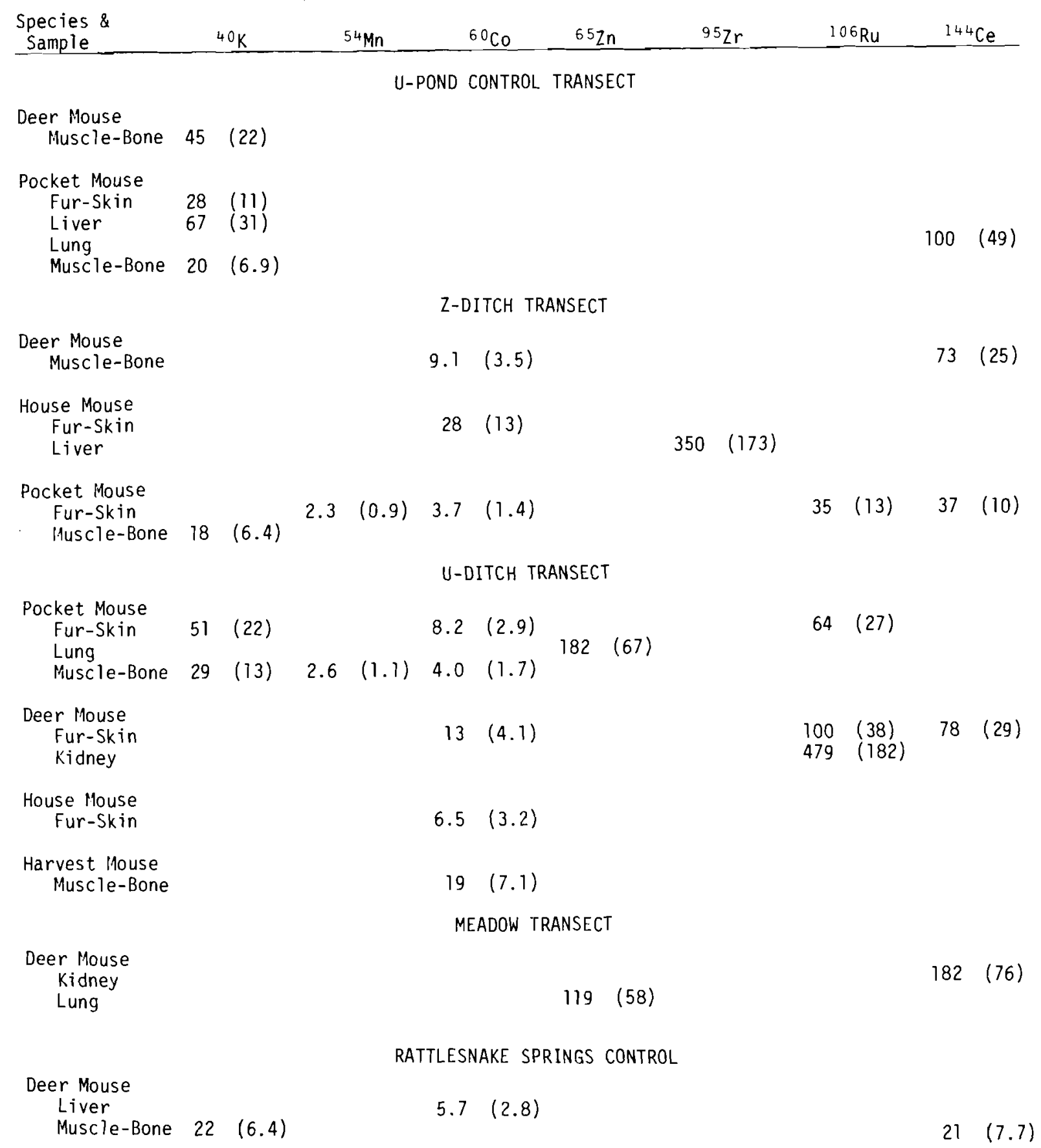


TABLE A.3. U-Pond Samples Collected During 1976-77 and Analyzed as Individual Animals, $\mathrm{pCi}{ }^{137} \mathrm{Cs} / \mathrm{g}$ Dry

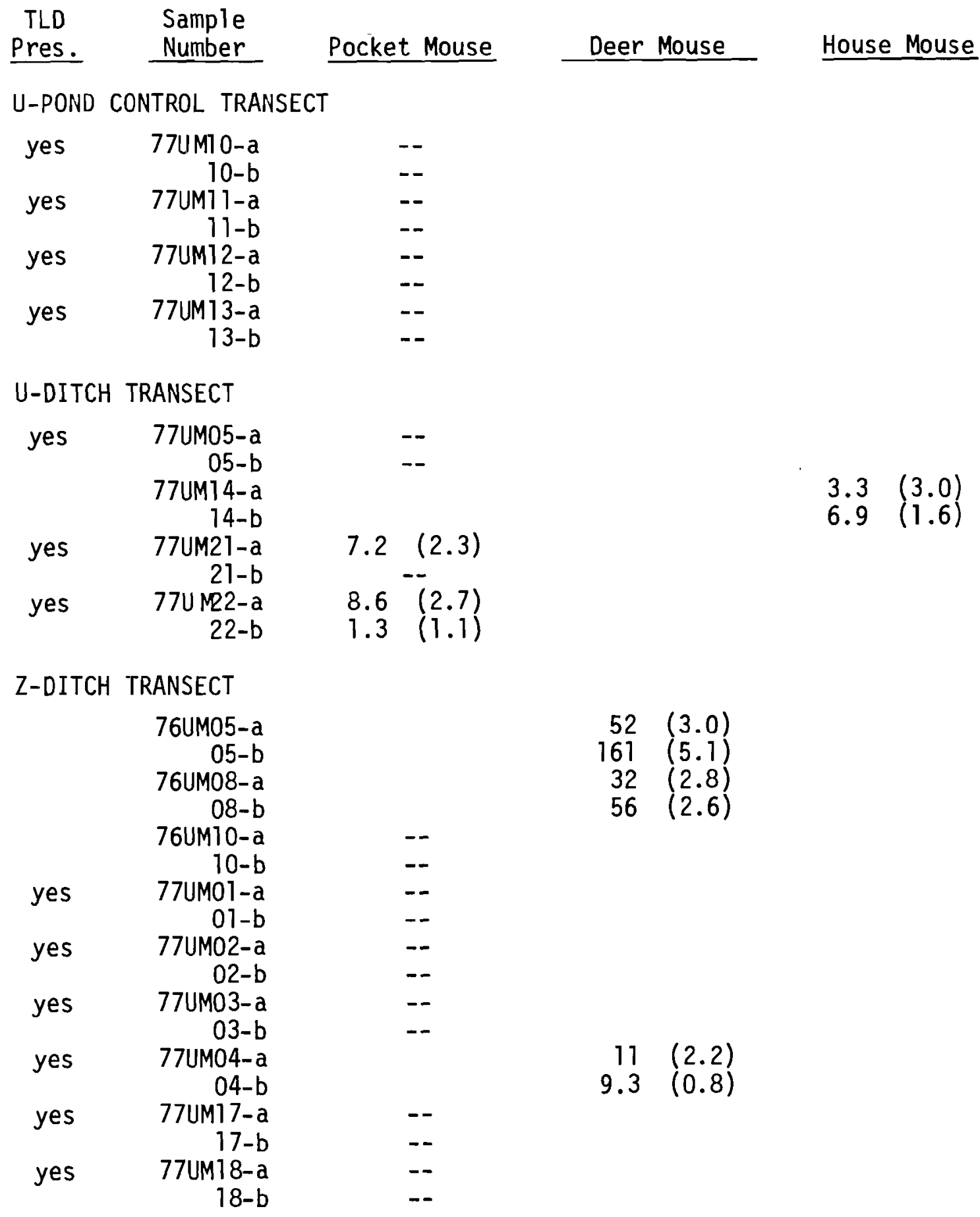


TABLE A.3. (Continued)

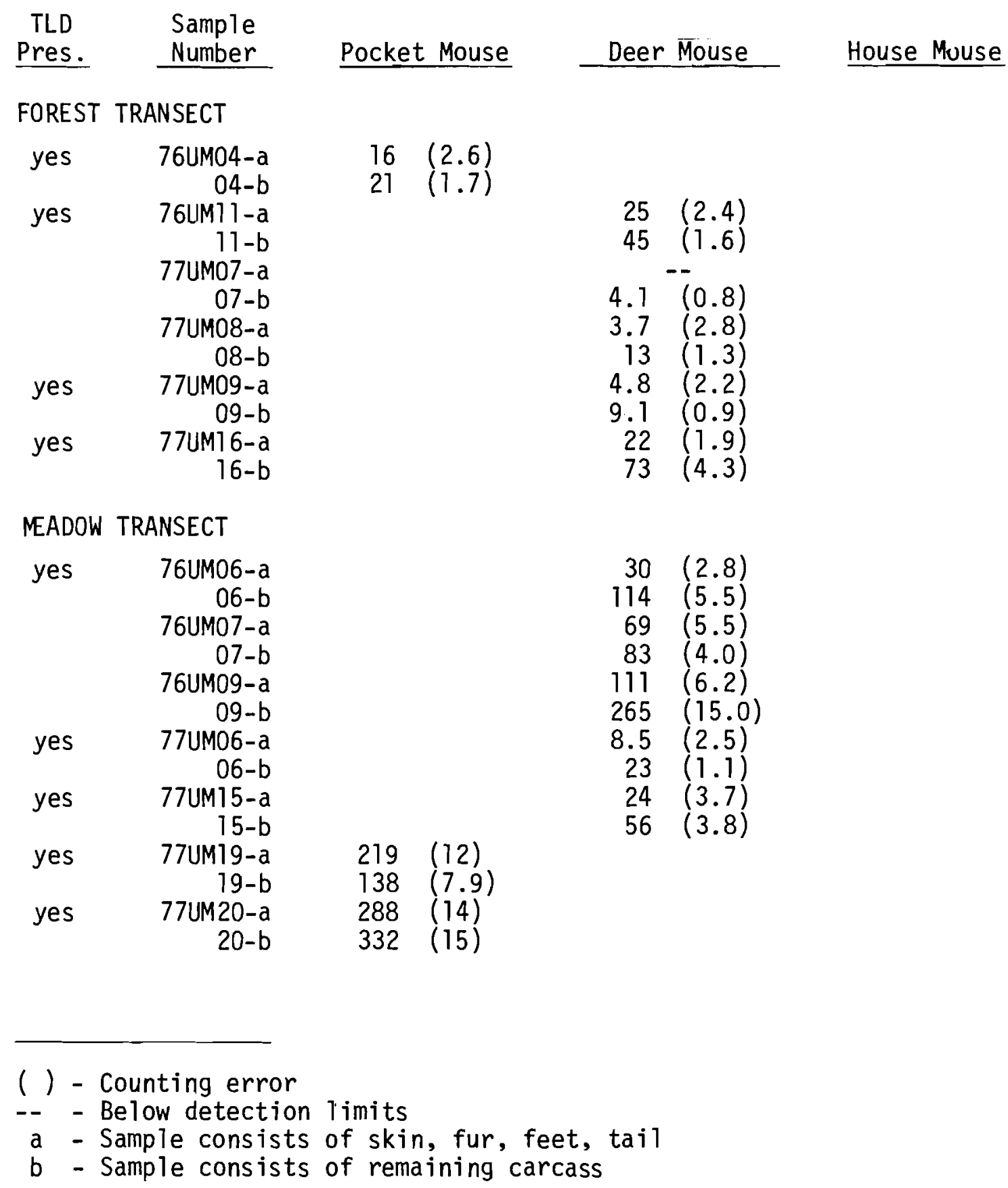


TABLE A.4. U-Pond Samples Collected During 1976-77 and

Analyzed as Individual Animals, PcI/g Dry

Samples Other Than ${ }^{137} \mathrm{Cs}$

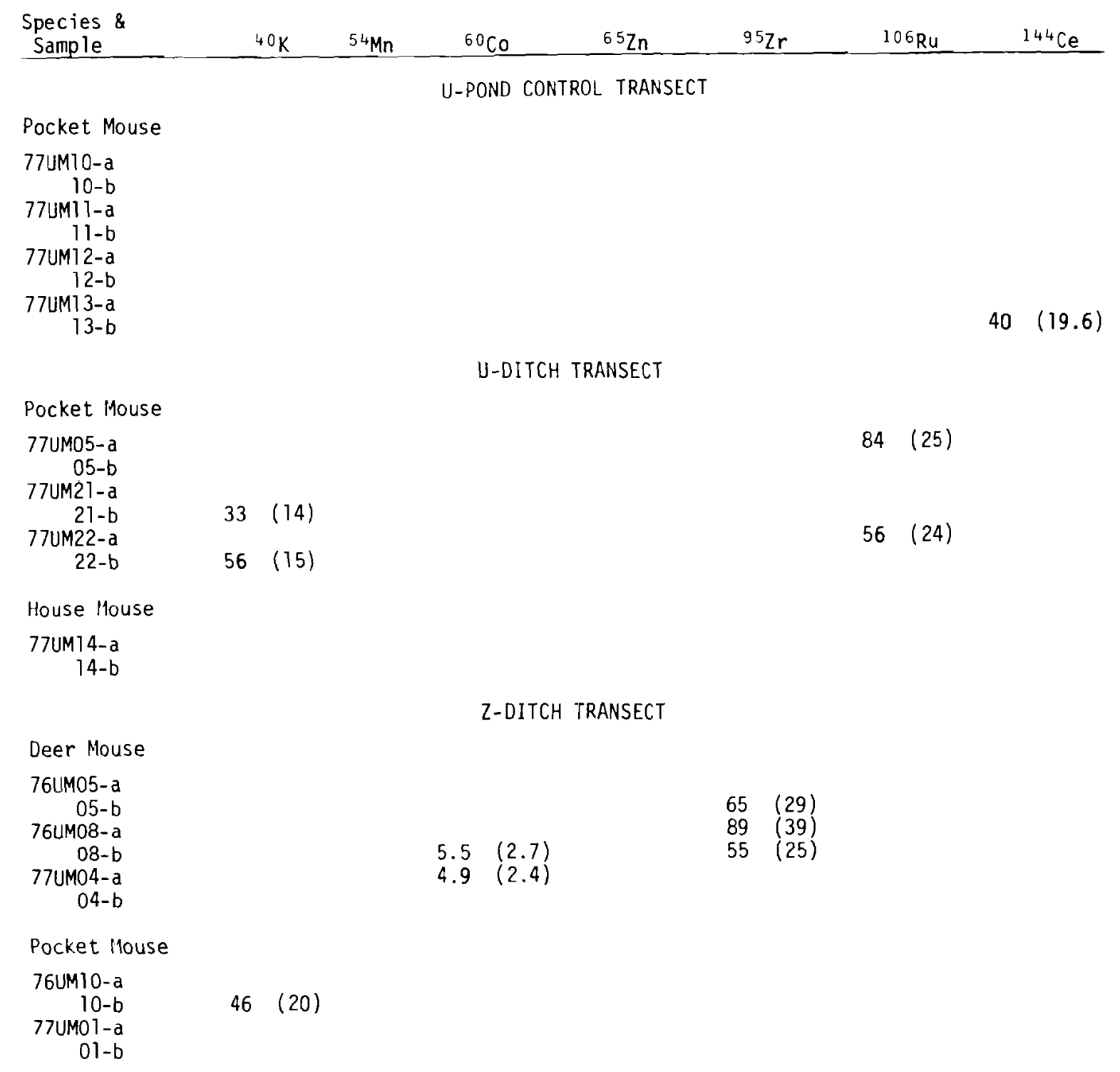




\section{TABLE A.4. (Continued)}

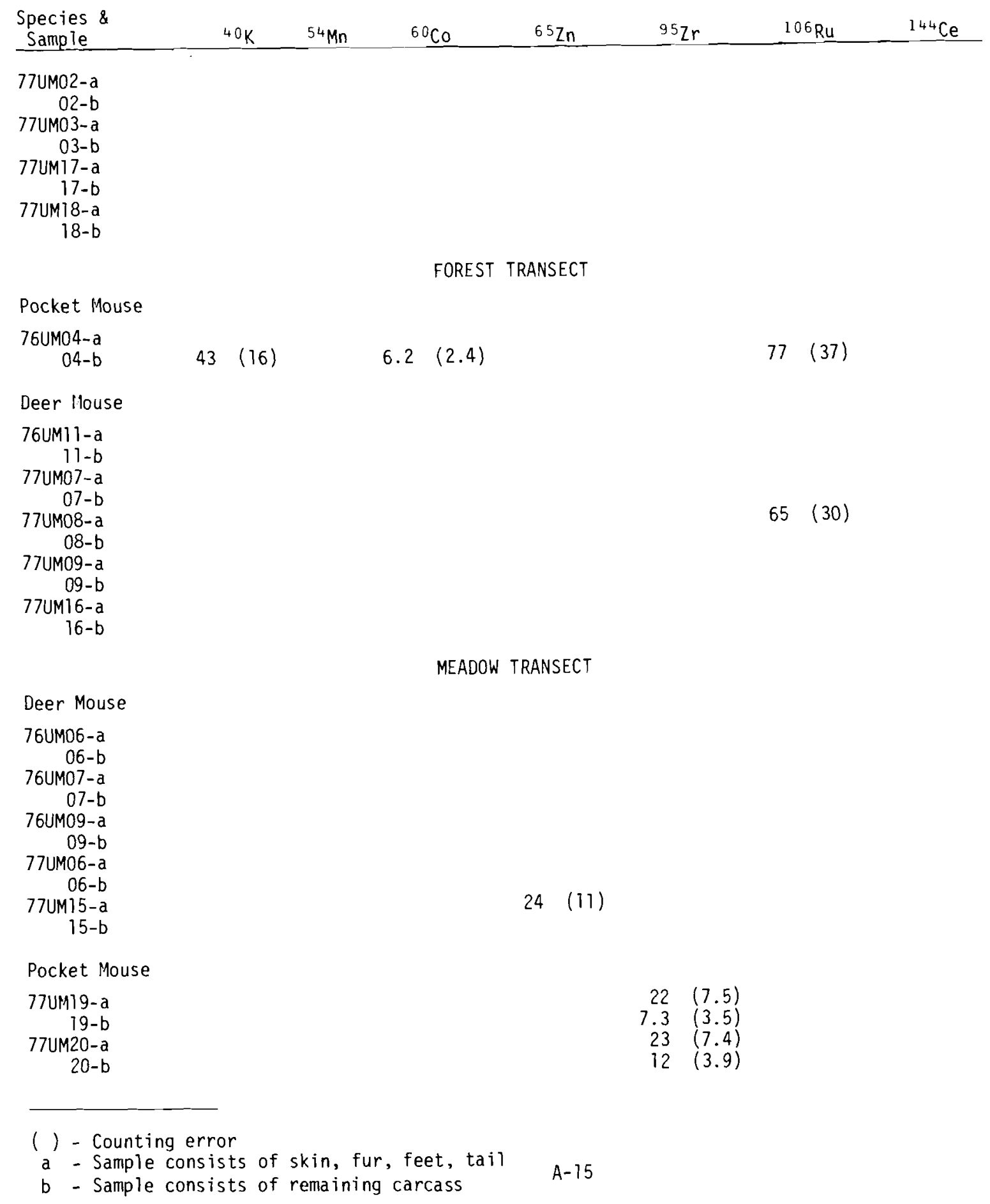




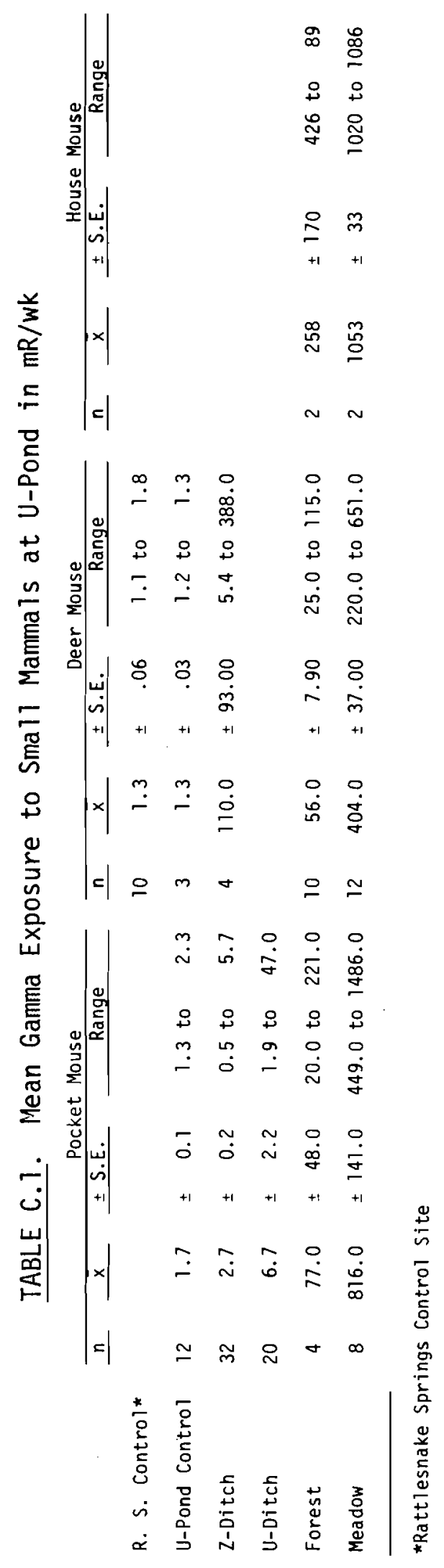




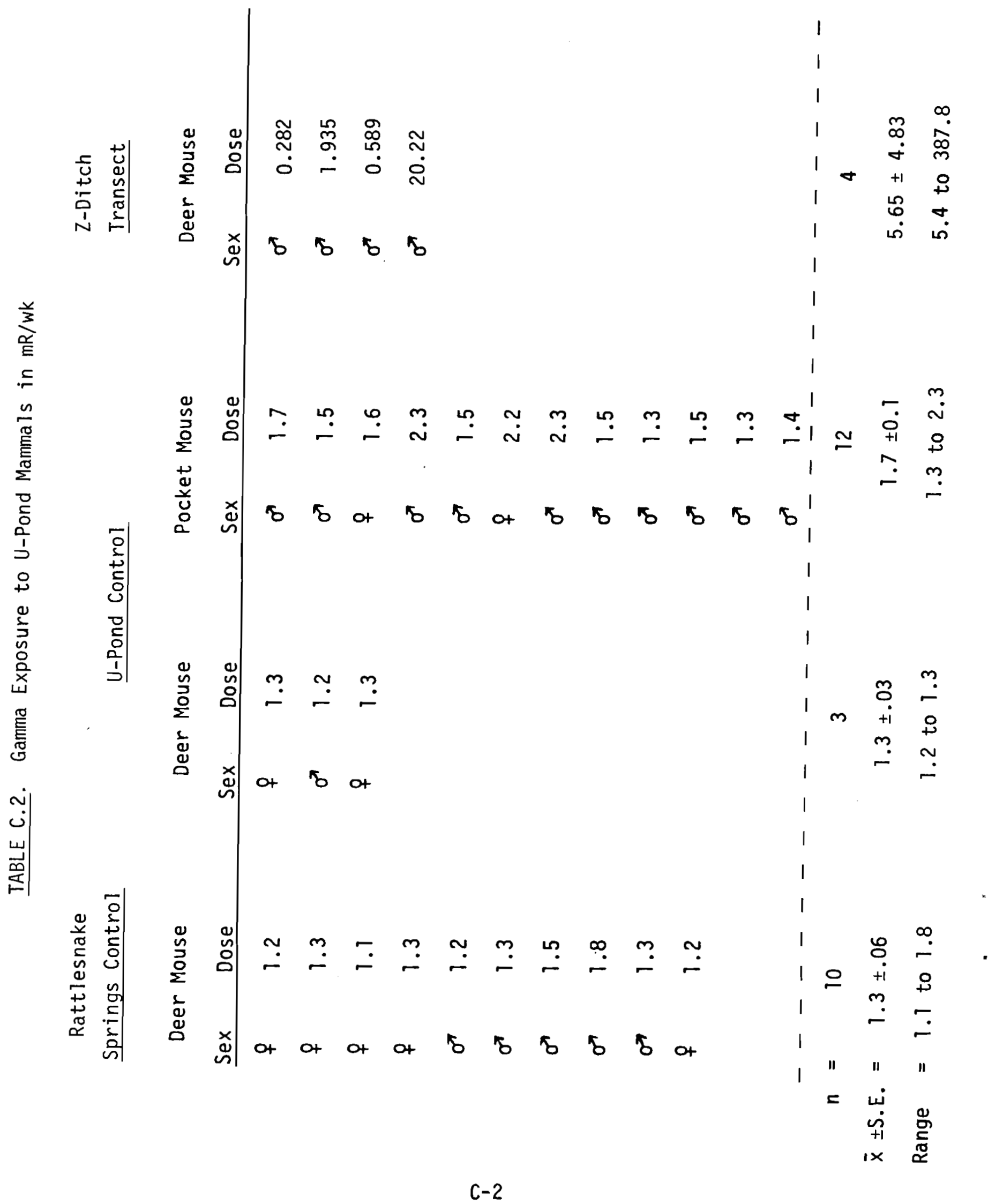




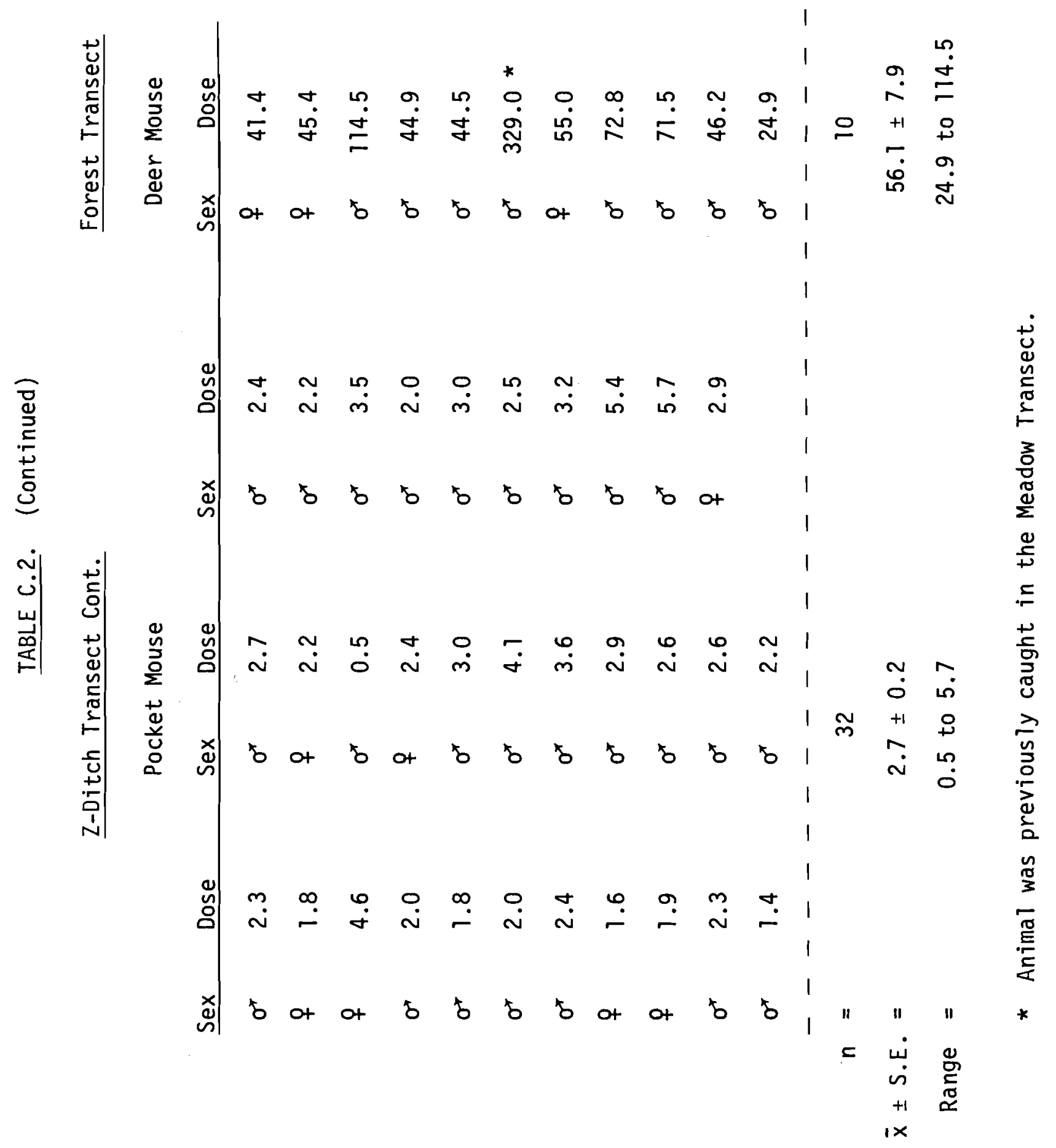


TABLE C.2. (Continued)

Forest Transect Cont. U-Ditch Transect

House Mouse Pocket Mouse Pocket Mouse

\begin{tabular}{|c|c|c|c|c|c|c|c|}
\hline Sex & Dose & Sex & Dose & Sex & Dose & Sex & Dose \\
\hline$\sigma^{*}$ & 426.4 & $\sigma^{*}$ & 33.8 & $0^{x}$ & 7.8 & $\sigma^{x}$ & 3.0 \\
\hline \multirow[t]{9}{*}{$\sigma^{x}$} & 88.5 & $\sigma^{*}$ & 221.2 & $q$ & 4.2 & $q$ & 2.1 \\
\hline & & $q$ & 19.7 & $q$ & 4.3 & $\sigma^{x}$ & 2.4 \\
\hline & & f & 32.3 & $\sigma^{*}$ & 3.0 & $\sigma^{*}$ & 11.6 \\
\hline & & & & $\sigma^{x}$ & 3.9 & $q$ & 4.4 \\
\hline & & & & $\sigma^{x}$ & 4.0 & $\sigma^{7}$ & 4.8 \\
\hline & & & & $\sigma^{x}$ & 10.9 & $\sigma^{x}$ & 5.2 \\
\hline & & & & $\sigma^{x}$ & 1.9 & $\sigma^{x}$ & 46.8 \\
\hline & & & & $\sigma^{x}$ & 2.3 & $\sigma^{*}$ & 5.7 \\
\hline & & & & $\sigma^{\pi}$ & 2.1 & f & 3.0 \\
\hline
\end{tabular}

$n=2$

4

20

$\bar{x} \pm$ S.E. $=258 \pm 170$

$76.8 \pm 48.3$

$6.7 \pm 2.2$

Range $=426$ to 89

19.7 to 221

1.9 to 46.8 


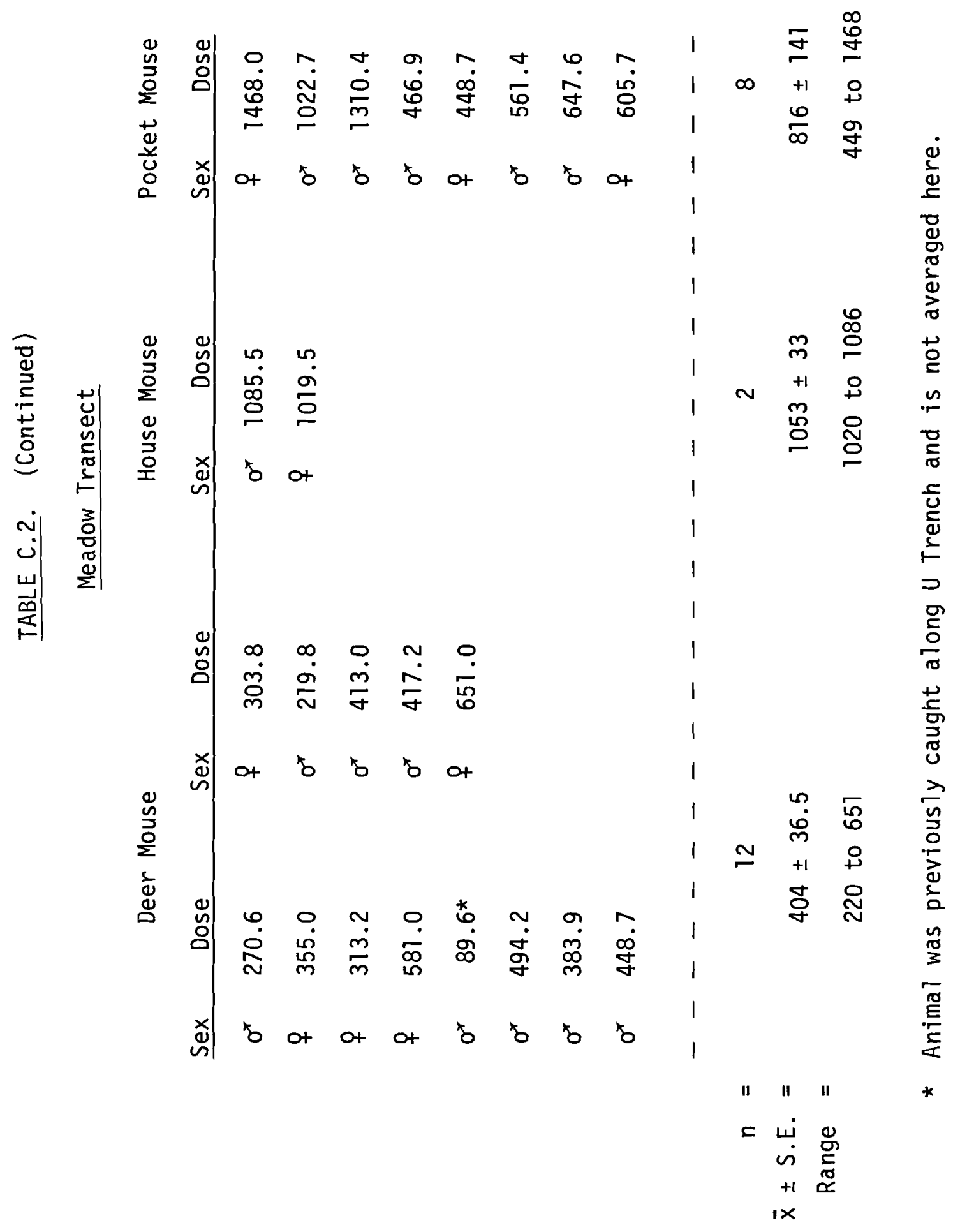


APPENDIX D

GAMMA AND NEUTRON EXPOSURES TO SOIL ALONG U-POND TRANSECTS 
TABLE D.1. Gamma Exposure in Soi1 A7ong U-Pond
Transects in Roentgens Per Year

\begin{tabular}{|c|c|c|c|c|c|c|c|}
\hline CONTROL TRA & & & & ter Lo & & & \\
\hline Soil Depth & $\# 1$ & $\# 2$ & $\# 3$ & $\# 4$ & $\# 5$ & $\bar{x}$ & S.E. \\
\hline $0 \mathrm{dm}$ & .084 & .073 & .073 & .073 & .084 & .077 & .002 \\
\hline $1 \mathrm{dm}$ & .084 & .084 & .084 & .084 & .084 & .084 & 0.0 \\
\hline $2 \mathrm{dm}$ & .104 & .104 & .094 & .094 & .084 & .096 & .003 \\
\hline $3 \mathrm{dm}$ & .073 & .104 & .094 & .104 & .084 & .092 & .006 \\
\hline $4 \mathrm{dm}$ & .104 & .104 & .094 & .104 & .084 & .098 & .004 \\
\hline $5 \mathrm{dm}$ & .115 & .094 & .094 & .104 & .115 & .104 & .005 \\
\hline
\end{tabular}

Z TRANSECT

Soil Depth

$\begin{array}{llllllll}0 \mathrm{dm} & .318 & .259 & .172 & .150 & .128 & .205 & .036 \\ 1 \mathrm{dm} & .102 & .102 & .095 & .088 & .077 & .093 & .005 \\ 2 \mathrm{dm} & .091 & .080 & .073 & .088 & .073 & .081 & .004 \\ 3 \mathrm{dm} & .099 & .084 & .084 & .088 & .080 & .087 & .003 \\ 4 \mathrm{dm} & .077 & .077 & .088 & .117 & .088 & .089 & .007 \\ 5 \mathrm{dm} & .084 & .113 & .080 & .117 & .099 & .099 & .007\end{array}$

U TRANSECT

Soil Depth

$\begin{array}{llllllll}0 \mathrm{dm} & .668 & .553 & .480 & .417 & .323 & .488 & .059 \\ 1 \mathrm{dm} & .177 & .157 & .157 & .272 & .125 & .178 & .025 \\ 2 \mathrm{dm} & .115 & .104 & .104 & .104 & .125 & .110 & .004 \\ 3 \mathrm{dm} & .104 & .094 & .104 & .094 & .094 & .098 & .002 \\ 4 \mathrm{dm} & .104 & .094 & .094 & .104 & .094 & .098 & .002 \\ 5 \mathrm{dm} & .125 & .125 & .125 & .125 & .115 & .123 & .002\end{array}$




\section{TABLE D.1. (Continued)}

\begin{tabular}{|c|c|c|c|c|c|c|c|}
\hline \multirow{2}{*}{$\begin{array}{l}\text { FOREST TRANSECT } \\
\text { Soil Depth }\end{array}$} & \multicolumn{7}{|c|}{ Dosimeter Locations } \\
\hline & $\# 1$ & $\# 2$ & $\# 3$ & $\# 4$ & $\# 5$ & $\bar{x}$ & S.E. \\
\hline $0 \mathrm{dm}$ & 14.2 & 4.50 & 11.9 & .542 & 2.69 & 6.78 & 2.67 \\
\hline $1 \mathrm{dm}$ & 23.2 & 3.19 & 8.88 & .230 & 2.71 & 7.64 & 4.14 \\
\hline $2 \mathrm{dm}$ & 6.23 & .824 & 3.41 & .125 & .814 & 2.28 & 1.14 \\
\hline $3 \mathrm{dm}$ & 1.90 & .334 & 1.70 & .115 & .407 & .892 & .376 \\
\hline $4 \mathrm{dm}$ & .699 & .354 & 4.59 & .115 & .292 & 1.21 & .850 \\
\hline $5 \mathrm{dm}$ & .354 & .208 & .303 & .135 & .365 & .273 & .044 \\
\hline
\end{tabular}

MEADOW TRANSECT

Soil Depth

$\begin{array}{lccccccc}0 \mathrm{dm} & 40.3 & 52.2 & 64.2 & 207 & 10.5 & 74.8 & 34.1 \\ 1 \mathrm{dm} & 36.7 & 80.1 & 51.9 & 199 & 7.80 & 75.2 & 33.1 \\ 2 \mathrm{dm} & 9.36 & 22.7 & 14.2 & 46.3 & 2.13 & 19.0 & 7.62 \\ 3 \mathrm{dm} & 3.66 & 9.09 & 4.06 & 14.5 & .584 & 6.37 & 2.44 \\ 4 \mathrm{dm} & 1.11 & 3.26 & 1.51 & 4.43 & .240 & 2.11 & .761 \\ 5 \mathrm{dm} & 1.42 & 1.54 & 1.06 & 3.37 & .230 & 1.53 & .516\end{array}$.



TABLE D.2. Neutron Exposure in Soil Along U-Pond
Transects in mrads Per Year

\begin{tabular}{|c|c|c|c|c|c|c|c|}
\hline \multicolumn{4}{|c|}{ COHTROL TRANSECT } & \multicolumn{4}{|c|}{ Dosimeter Locations } \\
\hline Soil Depth & $\# 1$ & $\# 2$ & \#3 & $\# 4$ & $\# 5$ & $\bar{x}$ & S.E. \\
\hline $0 \mathrm{dm}$ & 0.26 & 0.26 & 0.26 & 0.26 & 0.26 & 0.26 & 0.0 \\
\hline $1 \mathrm{dm}$ & 0.31 & 0.31 & 0.31 & 0.31 & 0.26 & 0.30 & 0.01 \\
\hline $2 \mathrm{dm}$ & 0.26 & 0.26 & 0.37 & 0.31 & 0.37 & 0.31 & 0.02 \\
\hline $3 \mathrm{dm}$ & 0.31 & 0.37 & 0.26 & 0.37 & 0.31 & 0.32 & 0.02 \\
\hline $4 \mathrm{dm}$ & 0.31 & 0.31 & 0.26 & 0.37 & 0.31 & 0.31 & 0.02 \\
\hline $5 \mathrm{dm}$ & 0.37 & 0.31 & 0.31 & 0.31 & 0.37 & 0.33 & 0.01 \\
\hline \multicolumn{8}{|l|}{ Z TRANSECT } \\
\hline \multicolumn{8}{|l|}{ Soil Depth } \\
\hline $0 \mathrm{dm}$ & 0.0 & 0.0 & 6.25 & 0.0 & 3.12 & 1.87 & 1.25 \\
\hline $1 \mathrm{dm}$ & 0.0 & 0.0 & 0.0 & 3.12 & 6.25 & 1.87 & 1.25 \\
\hline $2 \mathrm{dm}$ & 0.0 & 0.0 & 7.80 & 7.80 & 6.25 & 4.37 & 1.81 \\
\hline $3 \mathrm{dm}$ & 0.0 & 0.0 & 0.0 & 6.25 & 6.25 & 2.50 & 1.53 \\
\hline $4 \mathrm{dm}$ & 3.12 & 0.0 & 0.0 & 28.1 & 7.80 & 7.80 & 5.27 \\
\hline $5 \mathrm{dm}$ & 0.0 & 0.0 & 10.9 & 14.1 & 6.25 & 6.25 & 2.84 \\
\hline \multicolumn{8}{|l|}{ U TRANSECT } \\
\hline \multicolumn{8}{|l|}{ Soil Depth } \\
\hline $0 \mathrm{dm}$ & 0.52 & 0.52 & 0.52 & 0.42 & 0.42 & 0.48 & 0.02 \\
\hline $1 \mathrm{dm}$ & 0.31 & 0.31 & 0.26 & 0.21 & 0.26 & 0.27 & 0.02 \\
\hline $2 \mathrm{dm}$ & 0.26 & 0.31 & 0.37 & 0.31 & 0.37 & 0.32 & 0.02 \\
\hline $3 \mathrm{dm}$ & 0.31 & 0.37 & 0.26 & 0.31 & 0.37 & 0.31 & 0.02 \\
\hline $4 \mathrm{dm}$ & 0.31 & 0.26 & 0.31 & 0.31 & 0.37 & 0.31 & 0.02 \\
\hline $5 \mathrm{dm}$ & 0.37 & 0.31 & 0.37 & 0.31 & 0.31 & 0.33 & 0.01 \\
\hline
\end{tabular}


TABLE D.2. (Continued)

\begin{tabular}{|c|c|c|c|c|c|c|c|}
\hline \multicolumn{2}{|c|}{ FOREST TRANSECT } & \multicolumn{6}{|c|}{ Dosimeter Locations } \\
\hline Soil Depth & $\# 1$ & $\# 2$ & $\# 3$ & $\# 4$ & $\# 5$ & $\bar{x}$ & S.E. \\
\hline $0 \mathrm{dm}$ & 9.0 & 2.6 & 6.55 & 0.68 & 1.62 & 4.1 & 1.58 \\
\hline $1 \mathrm{dm}$ & 15.1 & 2.1 & 5.0 & 0.37 & 1.41 & 4.8 & 2.69 \\
\hline $2 \mathrm{dm}$ & 3.7 & 0.78 & 2.19 & 0.31 & 0.63 & 1.52 & 0.63 \\
\hline $3 \mathrm{dm}$ & 1.15 & 0.42 & 0.78 & 0.31 & 0.47 & 0.63 & 0.15 \\
\hline $4 d m$ & 0.37 & 0.31 & 0.37 & 0.26 & 0.37 & 0.34 & 0.02 \\
\hline $5 \mathrm{dm}$ & 0.37 & 0.26 & 0.37 & 0.37 & 0.42 & 0.36 & 0.03 \\
\hline
\end{tabular}

MEADOW TRANSECT

Soil Depth

$\begin{array}{lccccccc}0 \mathrm{dm} & 14.1 & 34.4 & 33.4 & 98 & 5.5 & 37.1 & 16.2 \\ 1 \mathrm{dm} & 19.8 & 27.7 & 19.8 & 109 & 2.92 & 35.8 & 18.7 \\ 2 \mathrm{dm} & 5.2 & 16.7 & 4.70 & 31.9 & 1.25 & 12.0 & 5.63 \\ 3 \mathrm{dm} & 2.09 & 4.70 & 2.61 & 8.1 & 0.70 & 3.64 & 1.29 \\ 4 \mathrm{dm} & 0.52 & 1.57 & 1.05 & 2.30 & 0.42 & 1.17 & 0.35 \\ 5 \mathrm{dm} & 0.0 & 1.57 & 0.52 & 1.83 & 0.37 & 0.86 & 0.37\end{array}$

TABLE D.3. Mean Gamma Exposure to Soil on U-Pond Transects in Roentgens Per Year

\begin{tabular}{|c|c|c|c|c|c|}
\hline $\begin{array}{l}\text { Soil Depth } \\
\text { in Decimeters }\end{array}$ & $\begin{array}{l}\text { Meadow } \\
\bar{x}+\text { S.E. } \\
\end{array}$ & $\begin{array}{l}\text { Forest } \\
\bar{x}+\text { S.E. }\end{array}$ & $\begin{array}{c}z_{-} \text {Transect } \\
\bar{x}+\text { S.E. } \\
\end{array}$ & $\begin{array}{c}\text { U. Transect } \\
\bar{x}+\text { S.E. }\end{array}$ & $\begin{array}{l}\text { Control } \\
\bar{x}+S . E . \\
\end{array}$ \\
\hline 0 & $74.8 \pm 34.1$ & $6.78 \pm 2.67$ & $0.21 \pm .036$ & $0.49 \pm .059$ & $0.08 \pm .002$ \\
\hline 1 & $75.2 \pm 33.1$ & $7.64 \pm 4.14$ & $0.09 \pm .005$ & $0.18 \pm .025$ & $0.08 \pm 0.0$ \\
\hline 2 & $19.0 \pm 7.62$ & $2.28+1.14$ & $0.08 \pm .004$ & $0.11 \pm .004$ & $0.10 \pm .003$ \\
\hline 3 & $6.37 \pm 2.44$ & $0.89 \pm 0.38$ & $0.09 \pm .003$ & $0.10 \pm .002$ & $0.09 \pm .006$ \\
\hline 4 & $2.11 \pm 0.76$ & $1.21 \pm 0.85$ & $0.09 \pm .007$ & $0.10 \pm .002$ & $0.10 \pm .004$ \\
\hline 5 & $1.53 \pm 0.52$ & $0.27 \pm 0.04$ & $0.10 \pm .007$ & $0.12 \pm .002$ & $0.10 \pm .005$ \\
\hline
\end{tabular}


APPENDIX E

SUMMARIES OF TRAPPING DATA 
TABLE E.1. Total Number of Individual Animals Captured Each Month

Pocket Mouse

Deer Mouse

House Mouse

Harvest Mouse

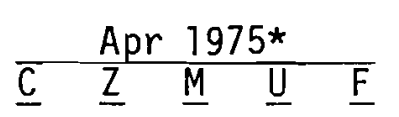

$$
\begin{array}{lllll}
\multicolumn{6}{c}{\text { May 1975* }} \\
\underline{\mathrm{C}} \stackrel{\underline{M}}{\underline{U}} & \underline{F}
\end{array}
$$

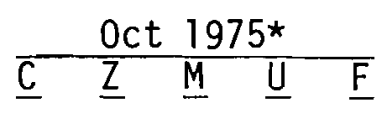

93

$\begin{array}{lll}2 & 4 & 2\end{array}$

2

$6 \quad 6 \quad 3$

2

$\begin{array}{lll}1 & 4 & 6 \\ 6 & & 4\end{array}$

$\begin{array}{ll}2 & 1 \\ & 1\end{array}$

1

2
4
1

$$
\frac{\operatorname{Mar} 1976^{\star}}{\text { R.S. }}
$$

Pocket Mouse

Deer Mouse

House Mouse

Harvest Mouse

$$
\frac{\text { May } 1976}{\underline{M} \quad \underline{\mathrm{V}} \quad \underline{\mathrm{F}} \quad \underline{\mathrm{U}} \quad \underline{\mathrm{F}}}
$$

\begin{tabular}{|c|c|c|c|c|c|}
\hline & \multicolumn{4}{|c|}{ Aug 1976} & Sep 1976 \\
\hline & $\bar{Z}$ & $M$ & $\bar{U}$ & $\underline{F}$ & $\mathrm{C}$ \\
\hline Pocket Mouse & 7 & 3 & 8 & 2 & 11 \\
\hline Deer Mouse & 2 & 2 & 1 & 2 & 5 \\
\hline House Mouse & & 1 & & 3 & \\
\hline
\end{tabular}

41

$\begin{array}{lll}5 & 1 & 3\end{array}$

$\begin{array}{llllllll}3 & 9 & 1 & 8 & 5 & 3 & 9 & 2 \\ 4 & 1 & 7 & 9 & 4 & 2 & & 2 \\ 4 & & 5 & & & 6 & & 2 \\ 3 & & 1 & & & & & \end{array}$

Harvest Mouse

*Animals captured during months were sacrificed for radiochemical analysis

$$
\begin{aligned}
\text { R.S. } & =\text { Rattlesnake Springs Control } \\
\dot{C} & =U \text {-Pond Control } \\
Z & =Z \text { Trench } \\
M & =\text { Meadow } \\
U & =U \text { Trench } \\
F & =\text { Forest }
\end{aligned}
$$

\begin{tabular}{lllllll}
\multicolumn{8}{c}{ Nov 1976 } \\
R.S. & $\frac{\text { C }}{\text { R }}$ & $\underline{Z}$ & $\underline{M}$ & $\underline{U}$ & $\underline{F}$ \\
& 8 & 5 & & 7 & \\
5 & 3 & 2 & 6 & & 2 \\
& & & 1 & &
\end{tabular}


TABLE E.1. (Continued)

Pocket Mouse

Deer Mouse

House Mouse

Harvest Mouse

Pocket Mouse

Deer Mouse

House Mouse

Harvest Mouse

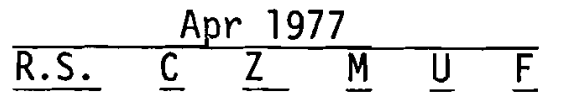

$\begin{array}{lllll}3 & 14 & 4 & 6 & 2\end{array}$

$\begin{array}{lllll}18 & 3 & 1 & 7 & 1\end{array}$

May 1977

R.S. $\quad \underline{Z} \quad \underline{M} \quad \underline{U} \quad \underline{F}$

$\begin{array}{llll}13 & 6 & 11 & 2\end{array}$

7

$\begin{array}{lll}5 & 1 & 3\end{array}$

1

* Animals captured during months were sacrificed for radiochemical analysis. 
TABLE E.2. Average Number of Animals Captured on U-Pond Transects Per Trap Session*

\begin{tabular}{|c|c|c|c|c|c|c|c|c|c|c|c|c|c|c|c|c|c|c|}
\hline & \multicolumn{3}{|c|}{$\begin{array}{c}\text { Rattlesnake } \\
\text { Springs }\end{array}$} & \multicolumn{3}{|c|}{$\begin{array}{l}\text { U-Pond } \\
\text { Control }\end{array}$} & \multicolumn{3}{|c|}{ Z-Trench } & \multicolumn{3}{|c|}{ Meadow } & \multicolumn{3}{|c|}{ U-Trench } & \multicolumn{3}{|c|}{ Forest } \\
\hline & $\underline{\mathrm{n}}$ & $\bar{x}$ & S.D. & $\underline{\mathrm{n}}$ & $\bar{x}$ & S.D. & $n$ & $\bar{x}$ & S.D. & $n$ & $\bar{x}$ & S.D. & $\underline{n}$ & $\bar{x}$ & S.D. & $\mathrm{n}$ & $\bar{x}$ & S.D. \\
\hline Pocket Mouse & & & & 8 & 7 & 2.5 & 11 & 7.1 & 3.5 & 13 & 1.9 & 2.2 & 13 & 5.5 & 3.2 & 13 & 0.9 & 0.9 \\
\hline Deer Mouse & 4 & 10.5 & 5.8 & 8 & 4.3 & 2.4 & 11 & 2.2 & 1.7 & 13 & 3.3 & 2.1 & 13 & 0.8 & 1.1 & 13 & 2.9 & 1.8 \\
\hline House Mouse & & & & & & & 11 & 0.1 & 0.3 & 13 & 1.9 & 2.2 & 13 & 0.2 & 0.4 & 13 & 1.5 & 1.9 \\
\hline Harvest Mouse & & & & & & & & & & 13 & 0.3 & 0.9 & & & & 13 & 0.4 & 0.5 \\
\hline
\end{tabular}

*Data from Apr, May, Oct 1975, Mar 1976, and Jul 1977 were omitted due to selective trapping for radiochemical analysis.

$n=$ Number of trapping sessions

i S.D. = Standard Deviation 


\section{DISTRIBUTION}

$\frac{\text { No. of }}{\text { Copies }}$

OFFSITE

A. A. Churm

DOE Chicago Patent Attorney

9800 South Cass Avenue

Argonne, IL 60439

(27)

DOE Technical Information Center

Department of Energy

R. C. Clusen

Assistant Secretary for

Environment

Washington, DC 20545

P. B. Dunaway

Nevada Operations Office

P.0. Box 14100

Las Vegas, NV 89114

J. L. Liverman

Deputy Assistant Secretary for Environment

Washington, DC 20545

0. D. Markham

Radiological and Environmental Sciences Laboratory

Idaho Operations Office

550 Second Street

Idaho Falls, ID 83401

S. Meyers

Office of Nuclear Waste

Management

Washington, DC 20545
No. of

Copies

OFFSITE

(8) DOE Office of Health and Environmental Research Washington, DC 20545
N. F. Barr
W. W. Burr
C. E. Carter
R. C. Dah Iman
R. E. Frank lin
W. S. Osburn
J. Swinebroad
R. L. Watters

0thers

S. I. Auerbach

Oak Ridge National Laboratory

P.0. Box X

Oak Ridge, TN 37830

I. L. Brisbin, Jr. Savannah River Ecology Laboratory Aiken, SC 29801

H. C. Burkholder

Office of Nuclear Waste Isolation

Battelle Memorial Institute 505 King Avenue

Columbus, $\mathrm{OH} 43201$

J. J. Davis

Office of Nuclear Regulatory Research

U.S. Nuclear Regulatory Commission

Washington, D.C. 20545 


\section{OFFSITE}

Lawrence Radiation Laboratory Lawrence Livermore Laboratory

Technical Information Dept., L-3 P.0. Box 2108

Livermore, CA 94550

T. E. Hakonson

Los Alamos Scientific Laboratory

P.0. Box 1663

Los Alamos, NM 86544

M. Smith, Director

Savannah River Ecology Laboratory

Drawer E

Aiken, SC 29801

F. W. Whicker

Radiology and Radiation

Biology Department

Colorado State University

Fort Collins, CO 80521

E. L. K lepper

Agricultural Research Service USDA

Pendleton, OR 97801

\section{ONSITE}

United Nuclear Inc.

T. E. Dabrowski

Hanford Engineering Development Laboratory

G. D. Carpenter

(10) DOE - Richland Operations

J. C. Cummings

0. J. Elgert/J. L. Roades

R. E. Gerton

B. R. Goranson

H. E. Ransom/F. Austin

M. W. Shupe

F. R. Standerfer/P. G. Harris

M. W. Tiernan/D. R. Elle

M. G. White/P. F. Dunigan

M. J. Zamorski
ONSITE

Rockwe11 Hanford Operations

H. Babad

D. J. Brown

L. E. Bruns

J. L. Deichman

R. D. Fox

R. J. Gimera

M. K. Harmon

W. F. Heine

R. E. Is aacson

J. E. Kinser

C. W. Manry

D. A. Marsh

H. E. McGuire

L. P. McRae

R. M. Mitche 11 (10)

G. C. Owens

D. Paine

J. V. Panesko

J. H. Roecker

J. A. Swenson

D. D. Wodrich

Pac if ic Northwest Laboratory

W. J. Bair

L. L. Cadwe 11

J. F. Cline

B. W. Compton (4)

L. L. Eberhardt

R. M. Emery

G. W. Endres

R. E. Fitzner

R. F. Foster

J. J. Fuquay

K. A. Gano (10)

J. Houston

D. C. Klopfer

D. E. Olson

K. R. Price

W. H. Rickard (5)

L. E. Rogers

R. G. Schreckhise

J. K. Soldat

W. L. Templeton (2)

C. M. Unruh

B. E. Vaughan (3)

Biology Library (3)

Technical Information (5)

Publishing Coordination (2)

NE 